\title{
Can heat shock protein 70 (HSP70) serve as biomarkers in Antarctica for future ocean acidification, warming and salinity stress?
}

\author{
Nur Athirah Yusof ${ }^{1}$ (1) $\cdot$ Makdi Masnoddin ${ }^{1} \cdot$ Jennifer Charles ${ }^{1} \cdot$ Ying Qing Thien $^{1} \cdot$ Farhan Nazaie Nasib $^{1}$.

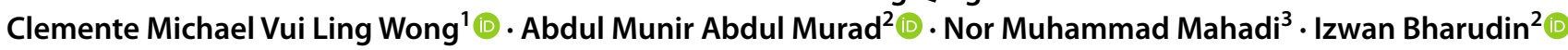

Received: 21 February 2021 / Revised: 30 December 2021 / Accepted: 10 January 2022 / Published online: 24 January 2022

(c) The Author(s) 2022

\begin{abstract}
The Antarctic Peninsula is one of the fastest-warming places on Earth. Elevated sea water temperatures cause glacier and sea ice melting. When icebergs melt into the ocean, it "freshens" the saltwater around them, reducing its salinity. The oceans absorb excess anthropogenic carbon dioxide $\left(\mathrm{CO}_{2}\right)$ causing decline in ocean $\mathrm{pH}$, a process known as ocean acidification. Many marine organisms are specifically affected by ocean warming, freshening and acidification. Due to the sensitivity of Antarctica to global warming, using biomarkers is the best way for scientists to predict more accurately future climate change and provide useful information or ecological risk assessments. The 70-kilodalton (kDa) heat shock protein (HSP70) chaperones have been used as biomarkers of stress in temperate and tropical environments. The induction of the HSP70 genes $(H s p 70)$ that alter intracellular proteins in living organisms is a signal triggered by environmental temperature changes. Induction of $H s p 70$ has been observed both in eukaryotes and in prokaryotes as response to environmental stressors including increased and decreased temperature, salinity, $\mathrm{pH}$ and the combined effects of changes in temperature, acidification and salinity stress. Generally, HSP70s play critical roles in numerous complex processes of metabolism; their synthesis can usually be increased or decreased during stressful conditions. However, there is a question as to whether HSP70s may serve as excellent biomarkers in the Antarctic considering the long residence time of Antarctic organisms in a cold polar environment which appears to have greatly modified the response of heat responding transcriptional systems. This review provides insight into the vital roles of HSP70 that make them ideal candidates as biomarkers for identifying resistance and resilience in response to abiotic stressors associated with climate change, which are the effects of ocean warming, freshening and acidification in Antarctic organisms.
\end{abstract}

Keywords HSP70 chaperone $\cdot$ Biomarker $\cdot$ Antarctica $\cdot$ Global warming $\cdot$ Heat stress $\cdot$ Salinity stress $\cdot$ Climate change $\cdot$ Bioindicators $\cdot$ Heat shock proteins

\section{Introduction}

Antarctic ice loss has accelerated at an astounding rate over the past four decades. The Antarctic shed ice at a rate of 40 billion tons from the year 1979-1990, and from 2009

Nur Athirah Yusof

nrathirah.yusof@ums.edu.my

1 Biotechnology Research Institute, Universiti Malaysia Sabah, 88400 Kota Kinabalu, Sabah, Malaysia

2 Department of Biological Sciences and Biotechnology, Faculty of Science and Technology, Universiti Kebangsaan Malaysia, 43600 UKM, Bangi, Selangor, Malaysia

3 Malaysia Genome Institute, Jalan Bangi, 43000 Kajang, Selangor Darul Ehsan, Malaysia onwards, the number rose to 252 billion tons per year-six times higher than the previous rate (Rignot et al. 2019). This rapid reduction in sea ice and similar environmental changes threaten biodiversity in the Antarctic, as they are happening over short time scales that do not accommodate natural selection (IPCC 2018). A scientific study suggests that melting ice from Antarctica could bring extreme weather and unpredictable temperature changes by disrupting ocean currents and changing levels of warming around the world (Golledge et al. 2019). Global warming is causing physical changes in Antarctica and altering the natural distribution of the living environment. All reports on the effects of global warming in Antarctica point out the importance of studying climate change to enable scientists to predict more accurately the effects of climate change on the ecosystem and to 
provide information for the world, especially for politicians and policymakers.

From a topographic point, most of the Antarctic ice is on land. With global warming, a lot of the melting comes from the bottom of the ice shelf, as it is exposed to the ocean. When the ocean warms up, the underside of the shelf melts and causes it to thin and eventually break off into the ocean, contributing to the rise in ocean levels. The melting of the ice shelf is contributing to the "freshening" of the ocean, as the excess of freshwater flows into the ocean. A study on the ocean "freshening" by glacial meltwater reported that increasing freshwater flows into the ocean interrupt the ocean's salinity and water buoyancy, which slows and eventually shuts down the vertical mixing of the ocean. When this happens, the cold waters at the surface cannot sink. The deeper waters retain their heat and trigger astounding ice melt from below (Silvano et al. 2018). The increase in heat trapped in the ocean is the major factor increasing sea levels and global climate change (Bronselaer et al. 2018). This increased melting exposes Antarctic organisms to novel environmental stressors, thus setting up the importance of biomarkers that can measure the effects of temperature rise and salinity due to the fact of water "freshening" as well as the ecosystem's tolerance limits, which include resistance and resilience to environmental change. As global warming is affecting polar ecosystems, we must learn the vulnerabilities that exist and the tipping points to inform global climate change policy. Otherwise, a unique opportunity may be lost.

Changes in temperature and salinity at the sea surface has been reported in several areas of the Antarctic Peninsula (Cárdenas et al. 2018) and King George Island (Bers et al. 2013). In addition to studying the effects of ocean warming, which causes increase in temperature and decrease in salinity at the sea surface, the effects of ocean acidification have caused significant variation in response patterns at the level of taxa of many marine organisms. It is undeniable that both ocean warming and acidification stressors are highly related, as the combined effects of these stressors have been reported worldwide such as in the Antarctic dragonfish, Gymnodraco acuticeps (Flynn et al. 2015); sea urchins, Sterechinus neumayeri (Ericson et al. 2012; Byrne et al. 2013; Suckling et al. 2015) and macroalgal (Schram et al. 2017); seagrasses and marine macroalgae (Koch et al. 2012); and Tropical Eastern Pacific coral, Porites panamensis (Anlauf et al. 2011). The increase in the carbon dioxide $\left(\mathrm{CO}_{2}\right)$ concentration in the atmosphere causes greenhouse effects. This will increase the temperature of sea surface and salinity, and when the $\mathrm{CO}_{2}$ dissolves into the sea surface, this will cause ocean acidification, which reduces ocean $\mathrm{pH}$. With regard to ocean acidification, several Antarctic species were identified as being vulnerable to elevated seawater $\mathrm{CO}_{2}$ level such as in the functioning of adult Laternula elliptica (Cummings et al. 2011), sensitivity of krill egg hatch rates (Kawaguchi et al. 2013), metabolic suppression in the pteropod Limacina helicina Antarctica (Seibel et al. 2012) and reduction in calcification of Limacina retroversa in the rapidly acidifying waters (Mekkes et al. 2021).

Studies of the living responses to environmental changes have led to the importance of understanding the vulnerability of a species to stress at the molecular level by looking at its heat shock proteins (HSPs). Among all HSPs, HSP70s are the most studied proteins due to the fact of their high sensitivity and abundance, as well as being ubiquitously expressed and associated with all subcellular compartments (Radons 2016). HSP70s are the central components of a cellular network of molecular chaperones and catalysts of protein folding processes (Frydman 2001; Mayer et al. 2005). Moreover, HSP70s have a cell cleaning function integrated into folding and signal transduction pathways, which allows them to revise the structures of newly synthesized proteins and repair unsuccessful protein conformations (Kampinga and Craig 2010). In bacteria, DnaK is the bacterial representative of the HSP70 chaperone family, which plays a key role in protein folding in non-stressed growth conditions and becomes more important during stress (Diamant et al. 2000; Sugimoto et al. 2003). For these characteristics of HSP70s, numerous studies have used HSP70s as biomarkers for their ability to signal possible environmental changes expressed in organisms through the expression of their genes and the consequent activation of the protein for its ability to increase or decrease according to the situation of the organism (Köhler et al. 1992; Zanger et al. 1996; Nadeau et al. 2001; Moyes and Schulte 2010; Mello et al. 2012; Silva-Zacarin et al. 2012; Taylor et al. 2013; Ansoar-Rodríguez et al. 2016; Coelho et al. 2017). Furthermore, HSP70s are typically used as biomarkers because they are key effectors in the stress response and generalists among the chaperones, making them the cellular first responders. Moreover, HSP70s reside in all subcellular compartments, and their abundance and high sensitivity which reflect their importance for cellular repair machinery and involvement in the homeostasis of all living organisms (Sharma and Masison 2009; Evans et al. 2010; Sabirzhanov et al. 2012; Mishra and Palai 2014).

Extensive studies documented the expression of $\mathrm{Hsp} 70$ as a response by marine organisms to the effects of climate change. These reported studies have investigated the response of marine organisms to global warming at the biological and molecular level. This review on the effects of climate change and $H s p 70$ expression in marine organisms is timely since: (1) ocean warming in Antarctic areas is occurring at an alarming rate and will continue to have strong impacts on marine organisms in the future; (2) a substantial amount of information on the expression of $\mathrm{Hsp} 70$ is publicly available; (3) there is no current comprehensive review on $H s p 70$ expression as a response to the effects of ocean warming on marine organisms. Hence, this review focuses 
on the $H s p 70$ expression as an effect of climate change and suggests future research and the application of $H s p 70 \mathrm{~s}$ as biomarkers to measure the impacts of climate change, particularly in the Antarctic oceans.

\section{Functional roles of HSP70}

Heat shock proteins (HSPs) are a family of highly homologous chaperone proteins that are induced in response to environmental, physical and chemical stresses. Many HSPs act as molecular chaperones to limit the consequences of damage and facilitate cellular recovery when cells are exposed to deviations from optimal growth conditions. These molecular chaperones are expressed in cells to protect unfolded aggregated proteins, thermally damaged proteins from aggregation and refold damaged proteins or target them for efficient degradation (Hartl and Hayer-Hartl 2002). When cells are exposed to stressors, many of the HSPs are synthesized and highly upregulated, particularly the HSP70 family. The HSP70 family plays a protective function in cell injuries by reducing the stress-induced denaturation and aggregation of intracellular proteins (Qu et al. 2015). The HSP70s are structurally and functionally conserved in evolution. HSP70s have high structural homology and conserved functional properties across species. These can be seen where the HSP70 in one organism can complement a different organism in protection from heat stress, such as the HSP70 in Drosophila melanogaster can complement mammalian HSP70, as demonstrated by Pelham et al. (1984), and rodent HSP70s can be functionally complemented by human HSP70 to grant cellular protection against various stresses (Jäättelä et al. 1992; Li et al. 1992; Angelidis et al. 1996).

HSP70 is a molecular chaperone that assist protein folding, disaggregation and degradation by the conformational changes fueled by adenosine triphosphate (ATP) hydrolysis (Zuiderweg et al. 2017). Catalytically, HSP70s prepare proteins for spontaneous and productive folding or unfold misfolded polypeptides that will then spontaneously refold (Fernández-Fernández and Valpuesta 2018). Interestingly, using molecular dynamics simulations, HSP70 chaperones can work as foldases themselves by directing the folding procedure of the substrate protein ( $\mathrm{Lu}$ et al. 2021). The ATP-dependent binding and release in HSP70 are initiated by the recognition of exposed hydrophobic residues in nonnative protein substrates (Imamoglu et al. 2020). In bacteria, HSP70 (DnaK) involved in many diverse protein folding processes in the cell such as assisting protein folding, preventing aggregation of stress denatured protein, and solubilizing protein aggregates (Mayer 2021). In addition, HSP70s also play important roles in biofilm formation and cell adhesion (Sugimoto et al. 2018) and aid in the virulence of many pathogenic bacteria (Ghazaei 2017). Most importantly, environmental stress insults, such as heat shock, lead to fold increase in HSP70s in many proteobacteria (Roncarati and Scarlato 2017; Schramm et al. 2017). In eukaryotes, many proteins require HSP70 for co-translational folding and catalyze substrate folding or refolding (Lang et al. 2021). Induction of HSP70 was extensively recorded when stress conditions reduced cells' viability and functions, such as oxidative, osmotic, heat, acid, and other distinct forms of proteotoxic stress (Lang et al. 2021).

However, more importantly, in terms of their role in stress response, HSP70s enable misfolded proteins to attain or recover their native states and also target degraded proteins and control their removal from the cell, thus preventing cytotoxic aggregates from forming (Parsell and Lindquist 1993; Hartl 1996; Fink 1999; Ciechanover and Kwon 2017). Classical activation of inducible HSP70s genesis in response to elevated environmental temperatures has been identified in most of the species examined to date. In all species, the induction of HSP70s is surprisingly rapid and intense, in part a consequence that it is an emergency response. Although the heat shock responses in an organism are universal, the induction temperature and the temperature fluctuations of the organism's environment are remarkably correlated. According to Mayer and Bukau (2005), HSP70s are the key aspects of the cellular network of molecular chaperones and folding catalysts. They assist in a wide range of protein folding processes in the cell by transiently attaching their substrate-binding domain with short hydrophobic peptide segments within their substrate proteins. The substrate binding and release cycle is driven by HSP70 shifting between the low-affinity ATP bound state and the high-affinity adenosine diphosphate (ADP) bound state. Therefore, for the chaperone activity of HSP70 proteins, ATP binding and hydrolysis are crucial both in vitro and in vivo.

\section{Structure and function of HSP70}

The HSP70 chaperone family is evolutionarily conserved in both prokaryotes and eukaryotes and widely distributed in the cytoplasm, mitochondrion, nucleus, endoplasmic reticulum, and other cell compartments (Boorstein et al. 1994). Although HSP70s are ubiquitous molecules, they are also induced in response to cellular stress. Canonical HSP70s as described by E. coli $\mathrm{Hsp} 70$ (DnaK), can inhibit protein misfolding/aggregation and refold misfolded proteins. HSP70 in prokaryotes, E. coli, called DnaK, is the bestknown heat shock protein, as much of our knowledge about HSP70 action is based upon studies on the DnaK (Makumire et al. 2015). Since bacterial and mammalian HSP70s are $50 \%$ identical and have substantially superimposable structures and similar enzymatic functions, it is believed that HSP70 chaperones across species perform through similar 
mechanisms. This theory is supported by biochemical and structural studies on HSP70s from several different species.

The mechanism of HSP70 is to interact with hydrophobic peptide segments of proteins in an ATP-controlled manner or by ATP hydrolysis and, consequently, mediate various functions, such as heat shock response, protein folding, refolding of misfolded proteins, protein translocation, and signal transduction (Young et al. 2003; Wruck et al. 2018). In addition, HSP70s bind rather non-specifically to hydrophobic peptides, thereby allowing HSP70s to act on a wide range of substrates to avoid non-productive interactions that would lead to aggregation and promote protein refolding (Sharma and Masison 2009).

In general, HSP70s comprise two common functional domains: (1) a conserved $44 \mathrm{kDa} \mathrm{N}$-terminal nucleotidebinding domain (NBD), also known as the ATP-binding domain (ABD), which is responsible for the binding and hydrolysis of ATP, and (2) a less conserved $28 \mathrm{kDa}$ C-terminal substrate-binding domain (SBD) which binds to the hydrophobic site of polypeptides and is connected by a highly conserved linker (Flaherty et al. 1990). Meanwhile, linkers are short peptide sequences that serve as covalent connectors between domains. They facilitate interdomain interactions as well as the cooperative function of domains (Gokhale and Khosla 2000; Ruiz et al. 2016). The significant feature of protein linker segments is their flexibility which is vital for interdomain communication. Flexible linkers are particularly important if a certain degree of movement and/ or interaction in the corresponding domains are required for efficient allosteric (Reddy Chichili et al. 2013). Although HSP70 members' linker residues are generally conserved, there seems to be some variation across distinct HSP70 subclusters. This variation in the linker residues could confer unique features to HSP70 members, as the linker is a structurally flexible motif capable of modifying the overall conformation of HSP70. Therefore, a study on the variations of linkers in HSP70 from different species may contribute to the elucidation of their special functions, particularly in stress response.

The NBD/ABD is composed of four subdomains, namely, IA, IB, IIA, and IIB arranged in two lobes as shown in the animation (Online Resource 1). Subdomain IA and IB interact with each other, while IIA interacts with IIB. Additionally, ATP binding is coordinated by all the subdomains that take place at the bottom of a cleft between subdomain IB and IIB. HSP70 NBD is often hydrophilic, while the SBD is further divided into two subdomains in which the $\beta$-sheet structure (SBD $\beta$ ) section is mostly hydrophobic to allow for the binding and folding of peptide substrates with hydrophobic residues, and an $\alpha$-helical structure (SBD $\alpha$ ) acts like a lid for SBD $\beta$ to promote the stable binding of a substrate (Zhu et al. 1996). Central to the chaperone function of HSP70 is the transition between open and closed conformations of
SBD which is regulated by ATP hydrolysis. The molecular mechanism of the ATPase cycle and substrate-binding/ release cycles are correlated to each other in regulating the HSP70 reaction cycle. HSP70 binds weakly to substrate in the ATP-bound state resulting in fast exchange rates, while in the ADP state, HSP70 bind to the substrate and reduce the release of a substrate (Han and Christen 2003). This basic mechanism is used to accomplish the many cellular functions of HSP70s. Conformational changes in NBD must be transmitted to the SBD to fulfil the ATPase-driven cycle. The ATP binding seems to facilitate flexibility between the base and the lid of the SBD by opening the peptide binding site effectively. Conversely, polypeptide binding in the SBD can also transfer alterations to the NBD, followed by the increasing ATP hydrolysis rate (Klaips et al. 2018).

To date, not much on the relationship between the HSP70 structural and functional analysis from Antarctic organisms has been elucidated. An interesting finding on Euplotes focardii HSP70 revealed several significant amino acid substitutions at the ATP-binding and substrate-binding domains (La Terza et al. 2004, 2007). It was postulated that these substitutions are probably part of adaptive strategies that promote an overall weakening of molecular forces in protein to confer more flexibility for conformational changes. The locations of the residue substitutions happen to be found in the substrate-binding pocket that is responsible for the conformational variations that regulate the HSP70 binding affinity to different substrates. In addition, the substitution of proline to alanine may decrease the steric limitations to functional sites, thus promoting flexible rotational in protein conformation. A recent study on HSP70 in Glaciozyma antarctica revealed several interesting findings, such as, the substitution of a $\beta$-sheet to loop in the N-terminal ATPase binding domain and some modest residue substitutions, which gave proteins the flexibility to function at low temperatures and retain their functional activity at ambient temperatures (Yusof et al. 2021). The suite of amino acid substitutions reported in the HSP70 in Antarctic organisms is consistent with the evolution of polypeptides flexibility to facilitate efficient folding activity for cold adaptation and retain their functions during thermal stress. However, more studies on HSP70 structural analysis particular in the Antarctic organisms still need to be conducted for us to obtain a clear perspective on how the adaptation strategies in HSP70 are related to their structures.

\section{Factors and conditions that modulate $\mathrm{Hsp} 70$ expression in temperate systems}

HSP70s respond to environmental stress and act as molecular chaperones to stabilize and refold non-native proteins or mark them for degradation (Deane and Woo 2011). This 
indirectly helps prevent persistent damage to other molecules and contributes to cell survival. However, HSP70s would also be detrimental to cellular function due to the high-energy and amino acid requirements as well as uncontrolled binding to cellular proteins (Krebs and Feder 1997). That means that the expression levels of HSP70 must be tightly regulated by the organism. The members of HSP70 family have different regulatory patterns at transcriptional level which are divided into three expression patterns: (1) strictly heat-inducible $H s p 70$, which are absent or exhibit a low basal level of expression under normal physiological conditions and considerably upregulated in response to proteotoxic stressors (Hsp 70$)$; (2) constitutively expressed and moderately heat-inducible $H s p 70$, which are expressed under normal physiological conditions and upregulated in response to stress (Hsp/Hsc70); (3) solely constitutively expressed and less stress-dependent $H s p 70$ genes, which provide folding of polypeptides are present in cells under all physiological conditions (heat shock cognates, Hsc70) (Sørensen 2010; Morris et al. 2013; Xu et al. 2018; Drozdova et al. 2019). It was reported that the inducible members of $H s p 70$ genes typically lack introns, while the constitutively expressed $\mathrm{Hsc} 70$ typically contain several introns in the coding sequence (Metzger et al. 2016; Xu et al. 2018). Although the features of the inducible $H s p 70$ and $H s c 70$ are related to the absence of introns in the corresponding genes and in addition to the presence of specific heat shock elements in their promoters as well as specific amino acid signatures and sequence similarity with other inducible forms, no clear evidence for consistent interspecies identification of inducible $\mathrm{Hsp} 70$ or $\mathrm{Hsc} 70$ forms has been presented so far (Morris et al. 2013). In fact, a study by Drozdova et al. (2019) suggested that the $H s p 70$ and $H s c 70$ gene family, within the order Amphipoda, diversified into cognate and heat-inducible paralogs independently from other crustaceans. Thus, the $\mathrm{Hsp} 70$ and $\mathrm{Hsc} 70$ gene family types in distant taxa may not be identified only by sequence similarity. In the Antarctic copepod, Tigriopus kingsejongensis, the Hsp70 transcript profile was highly upregulated under instantaneous salinity change (Kim et al. 2022), which place them in the group of strictly inducible $H s p 70$ genes. In Trematomus bernacchii, there was no apparent difference in the number or pattern of isoforms of $H s p 70$ in gill tissue among Antarctic and New Zealand notothenioids (Carpenter and Hofmann 2000). This study shows that constitutive expression of some members of the $H s p 70$ family in $T$. bernacchii belong to the constitutively expressed and less stress-dependent, whereby the Hsp70 genes' expression are relatively highly expressed in control and treated samples with no significant expression between groups. Interestingly, in contrast with a study done by Huth and Place (2016), they reported moderate increases in $H s p 70$ transcripts in $T$. bernacchii when cells were exposed to temperature and pressure of carbon dioxide $\left(\mathrm{pCO}_{2}\right)$ stressors simultaneously, which place the Hsp 70 s in the group of constitutive and moderately heat-inducible $H s p 70$ genes.

Previous studies have described that in most organisms, $H s p 70$ genes are activated in response to elevated environmental temperatures or heat shock response (Clark and Peck 2009; Silver and Noble 2012). For instance, the marine mollusc, L. elliptica and Nacella concinna, demonstrated significant upregulation of $H s p 70$ gene expression in response to acute $2 \mathrm{~h}$ heat shock experiment (Clark et al. 2008a). Despite this, the expression of $H s p 70$ is not limited to heat stress. In humans, a wide range of stress is capable of inducing the expression of the members of the HSP70 family (Radons 2016). In Arabidopsis, all members of the Hsp 70 s family showed up to a 20 -fold induction by heat shock treatment, except the mitochondrial and chloroplast Hsp70s (Sung 2001). The expression levels of the Antarctic moss, Pohlia nutans Hsp 70, also showed a higher increase when treated with cold shock as compared to heat shock treatment (Liu et al. 2014). The selective response to low temperature may be related to the increasing demand for a molecular chaperone function at low temperatures in the plant cell (Liu et al. 2014). This shows that the upregulation of $H s p 70$ s also responds to other proteotoxic stressors other than heat (Feder and Hofmann 1999).

Numerous studies have shown that HSP70s are vital to organisms' responses to various environmental stresses, particularly heat, drought, salinity, acidity, cold, ultraviolet (UV) radiation, and exposure to heavy metals (Yu et al. 2015). Although several reports have shown that Antarctic marine species became unresponsive to thermal stress, still, these organisms maintained the genes related to stress response (Clark and Peck 2009). This suggests that genes may need to be activated in response to multiple stressors. In other organisms, the upregulation of $H s p 70$ is observed when cells are exposed to a variety of stressors. It was found that the expression of chloroplast $H s p 70$ genes of Chlamydomonas increased in response to heat shock as well as high light or oxidative stress conditions (Schroda et al. 1999). This suggests that chloroplast $H s p 70$ s are regulated by environmental factors such as light, heat, and pathological stresses. Hsp70 in maize (Zea mays) also showed a response to drought stress imposed by placing the seedlings in a PEG solution (Hu et al. 2010). The expression level of P. nutans Hsp70 was also upregulated in response to drought treatment by both water deprivation or PEG6000 solution (Liu et al. 2014). In addition, the $P$. nutans $H s p 70$ expression level also significantly increased in response to salinity and UV radiation. Significant salt sensitivity was also reviewed on the Ssb class of Saccharomyces cerevisiae HSP70 family (Peisker et al. 2010). Human Hsp70s were also demonstrated to be upregulated in the cellular response to diseases including neurological disorders, cancer, and virus 
infection (Radons 2016). This is supported by a previous study in Alzheimer's disease models that demonstrated the induction of $\mathrm{Hsp} 70$ in response to protein misfolding caused by the disease (Jinwal et al. 2009).

\section{HSP70 expression changes in Antarctic organisms exposed to heat, salinity and $\mathrm{pH}$ stressors}

The Antarctic Peninsula is facing thinning and retreat of ice shelves causing the rate of ice loss to nearly quintupled from 7 to 33 billion tons a year during the twentieth century due to both the atmosphere and ocean warming (IPCC 2018, Siegert et al. 2019). With ocean warming resulting in more sea ice melt simultaneously as oceanic $\mathrm{CO}_{2}$ levels are increasing, the increase in sea surface temperature and decrease in salinity and $\mathrm{pH}$ are exposing marine lives to environmental stress situations (Mimura 2013). The effects of sudden changes in the sea surface has been reported in several studies such as the high mortality of krill near Carlini Station, King George Island (Fuentes et al. 2016) and the loss of ability to adapt to sudden changes in water such as in scallops (Adamussium colbecki), clams (L. elliptica) and limpets ( $N$. concinna) (Peck 2005; Peck et al. 2010), marine invertebrates (Odontaster validus and Paraceradocus gibber) (Clark et al. 2008a, b, c), and sea urchins (S. neumayeri) (González-Aravena et al. 2018). Moreover, the intertidal limpet, Cellana toreuma, showed a significant increase in $H s p 70$ expression for coping with ocean acidification and elevated temperature (Wang et al. 2018). Yusof et al. (2021) reported that the Antarctic yeast, G. antarctica, showed increasing expression of Hsp70s upon thermal stress. It was reported that many Antarctic marine invertebrates were incapable of upregulating the expression of HSP70 at the transcript and protein levels. Nevertheless, extensive studies on $H s p 70$ expression have shown that some Antarctic species can generate $H s p 70$ during heat, salinity, and $\mathrm{pH}$ stress. The significant regulation of Hsp70 expression in Antarctic marine ecosystems provide good model species for studying the effects of heat, salinity, and $\mathrm{pH}$ stressors in the ocean. Therefore, $H s p 70$ could be used as a biomarker in these organisms to evaluate environmental stressors including increased temperature and decreased salinity and $\mathrm{pH}$. Here we provide some of the findings on $H s p 70$ expression level when cells were exposed to heat, salinity, and $\mathrm{pH}$ stress documented in a variety of organisms, focusing more on Antarctic species. Information on the HSP70 studies, including the type of samples and methods of collection and detection described in several studies, are summarized in Table 1.

\section{Prokaryotes}

Studies on the $H s p 70$ expression level using transcriptomics and proteomics have extensively been conducted in eukaryotes compared to the expression level of DnaK in prokaryotes. The DnaK molecular mechanisms of adaptation have not been as comprehensively investigated, especially the expression of DnaK in prokaryotes when cells are exposed to thermal and salinity stress. Here, we gathered some of the findings of DnaK expression in Antarctic prokaryotes focusing on bacteria and archaea.

\section{Bacteria}

In bacteria, DnaK is an Hsp70 homolog that plays a role as a cellular thermometer and is equally vital for responses to abiotic stressors such as thermal, salinity, drought, limited nutrient and chemical exposures (Yu et al. 2015). In terms of amino acid sequence, the bacterial DnaK is approximately 50\% identical to the eukaryotic HSP70 (Evans et al. 2010). The expression of DnaK increases when cells are exposed to stress, which plays a significant role in the refolding of thermally damaged proteins. In addition, DnaK also plays a role in assisting in the folding of nascent protein chains under normal growth conditions (Abdullah-Al-Mahin et al. 2010). High expression levels of DnaK have shown that it has protective roles in E. coli growth between 20 and $40{ }^{\circ} \mathrm{C}$ (Genevaux et al. 2004). Studies have shown that DnaK carries out key functions to enhance microbial resistance towards stress. Xu et al. (2017) demonstrated that heterogeneous expression of DnaK from Alicyclobacillus acidoterrestris improved $E$. coli resistance towards heat, acid, and cold stresses. Sinnasamy et al. (2016) showed that bacteria overproducing DnaK enhanced shrimp resistance against the pathogen Vibrio harveyi, which infects aquatic animals. In pathogens, such as Streptococcus mutans, DnaK is involved in the survival of pathogens in extreme environments and contributes to the virulence of $S$. mutans (Jayaraman and Burne 1995). Although not much was found on the expression of DnaK in Antarctic bacteria related to heat and salinity stress, an interesting study on an Antarctic psychrotroph, Shewanella sp. Ac10, demonstrated accumulation of intracellular DnaK when cells were exposed to low temperature (Yoshimune et al. 2005). This study also found that the recombinant Shewanella DnaK gene enabled the E. coli mutant to grow at $15{ }^{\circ} \mathrm{C}$. In psychrophilic bacteria, Shewanella frigidimarina, grown at 4,20 and $28{ }^{\circ} \mathrm{C}$, a proteomics study showed the abundance of DnaK when cells were exposed to $28{ }^{\circ} \mathrm{C}$ (García-Descalzo et al. 2014). These findings show the important role of DnaK when cells are exposed to stress conditions. DnaK act as preponderant molecular chaperones in preventing the formation of protein misfolds and aggregates that are toxic to the cells. 


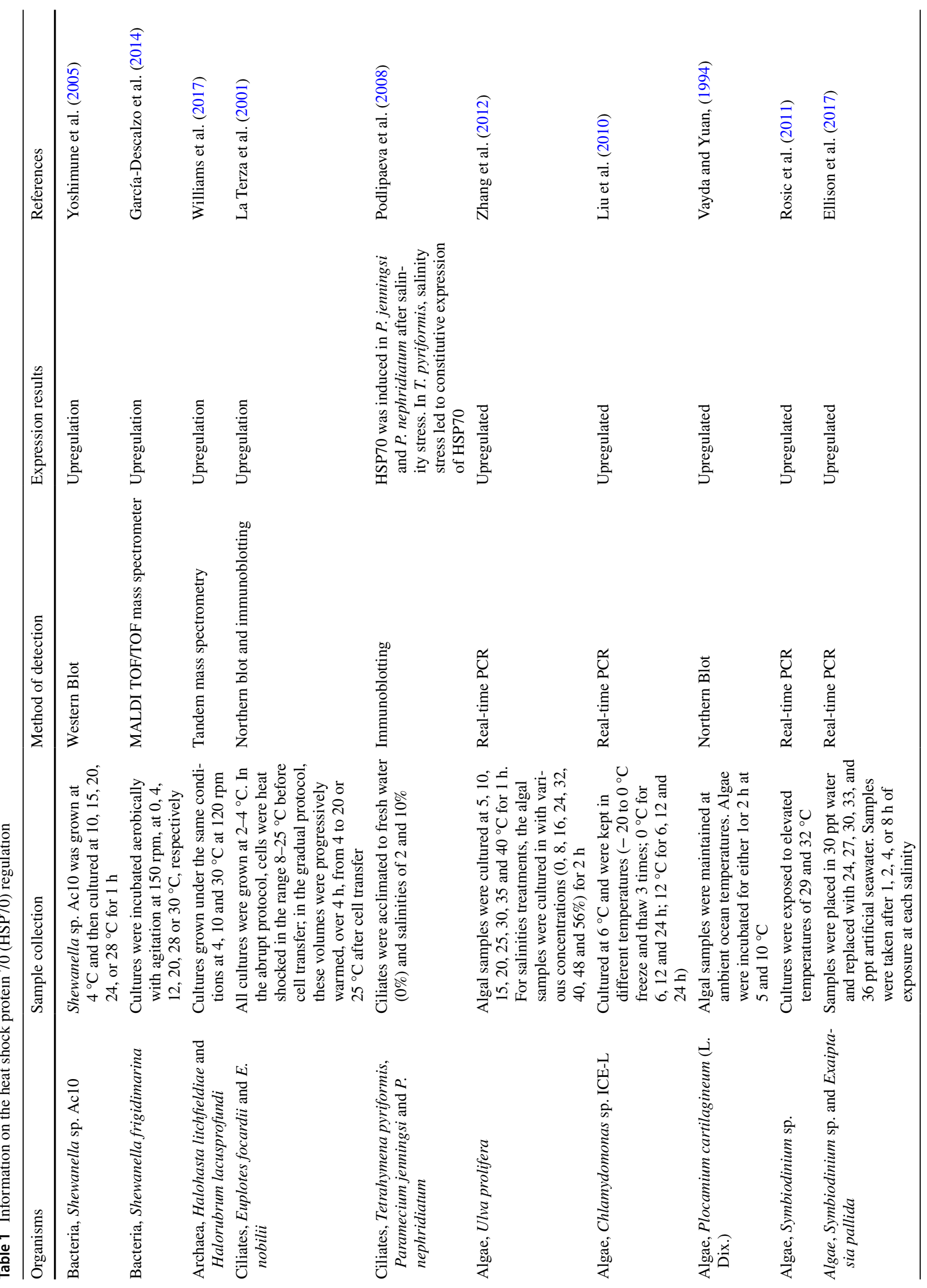




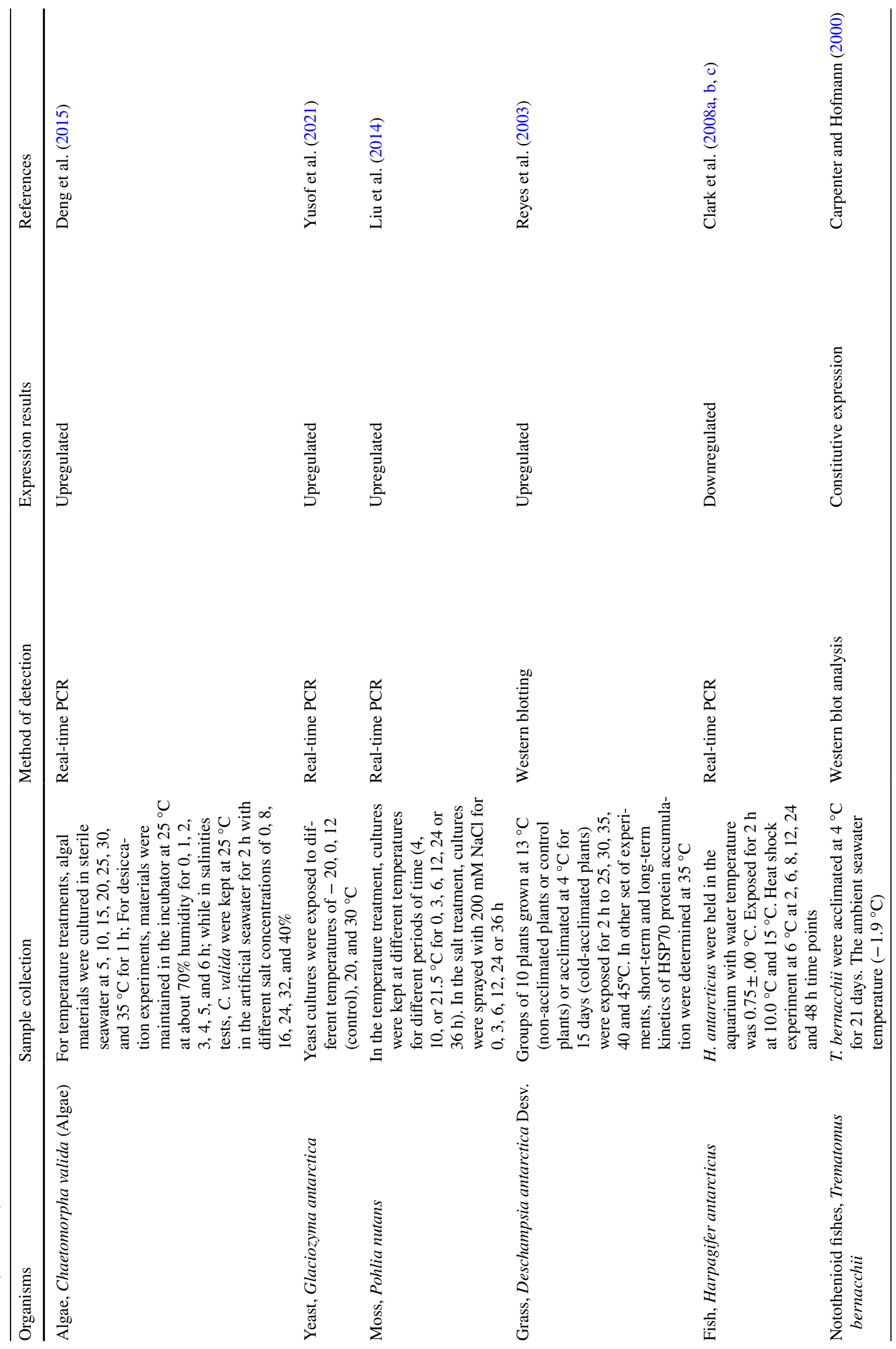



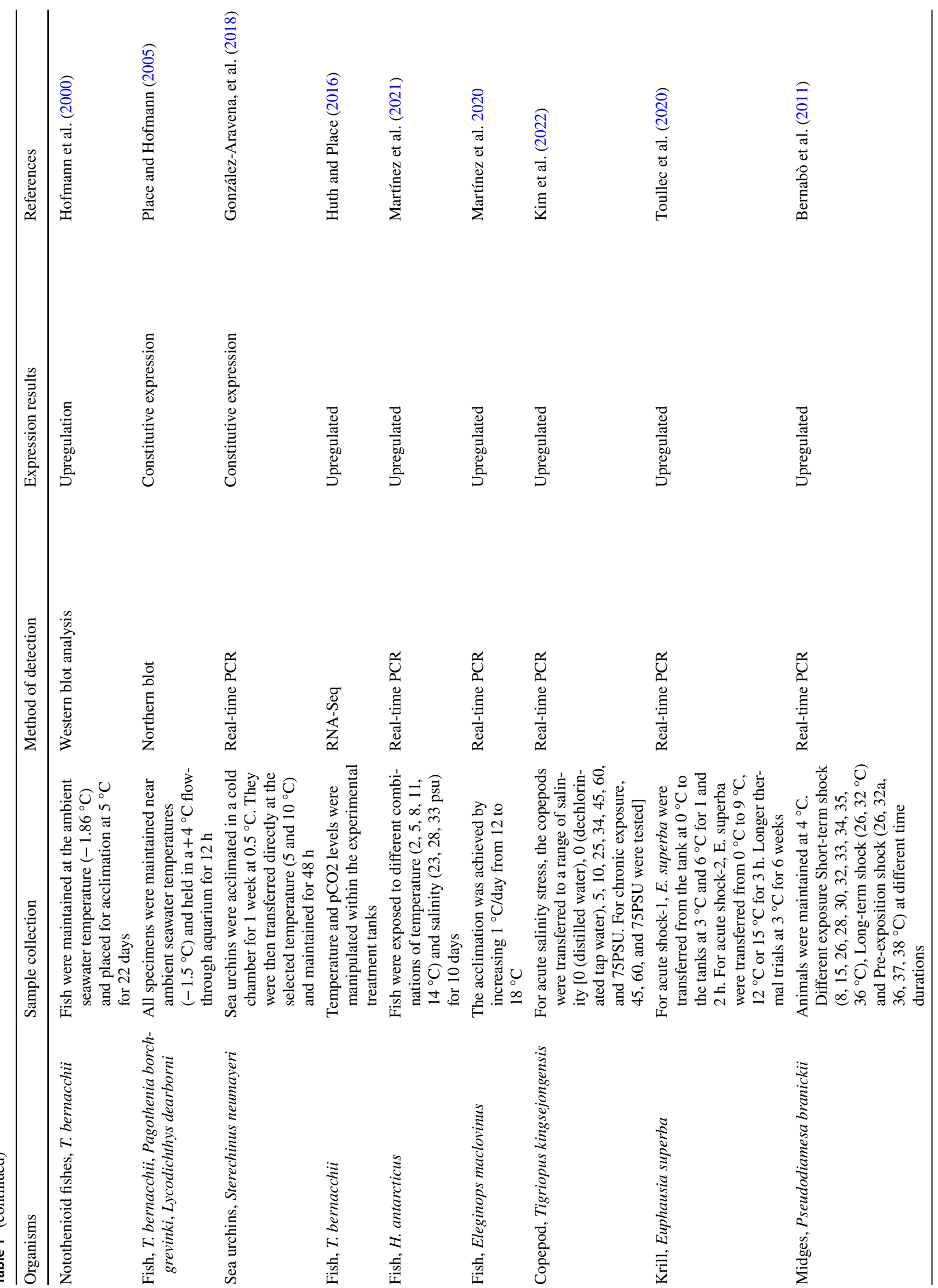


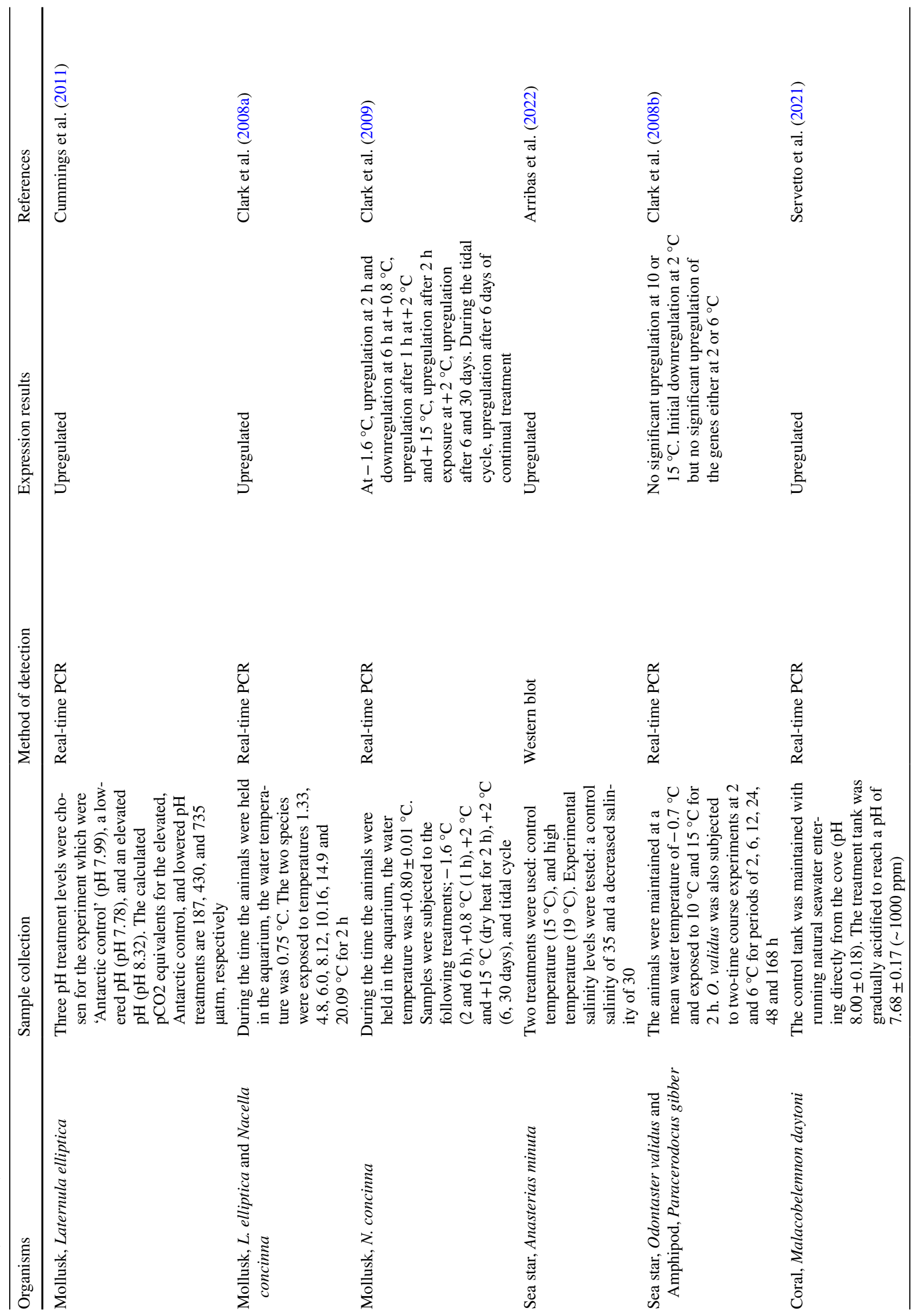




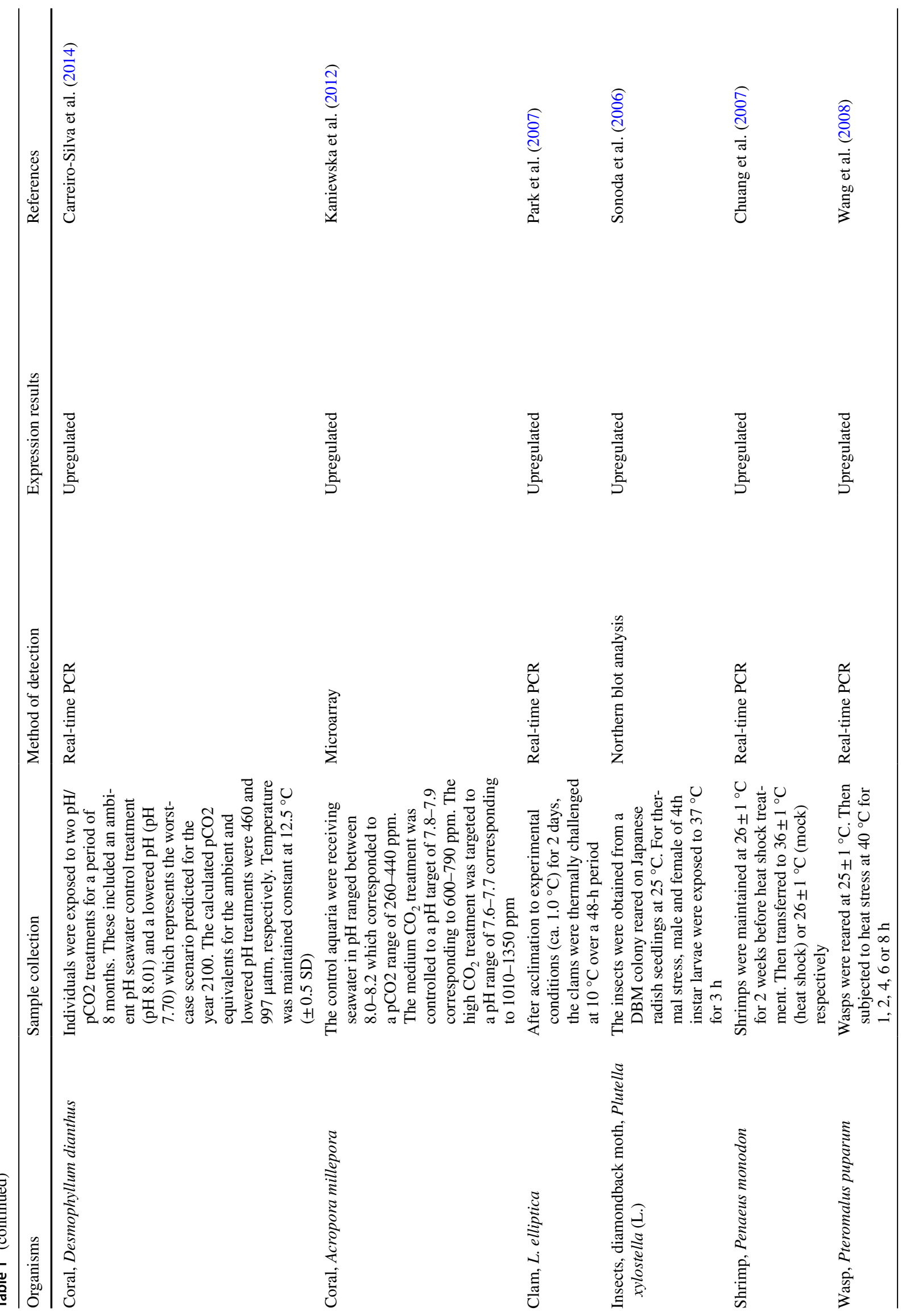


The DnaK stress response is vital for bacteria in adapting to changes caused by environmental stressors in their physiological state.

\section{Archaea}

HSP70 and DnaK have been extensively studied in many organisms, but little is known about them in archaea. The archaeal DnaK primary structure is more like bacterial compared to eukaryotic homologues. Not all archaea possess the stress protein HSP70 (DnaK), in contrast with bacteria and eukaryotes, which possess it without any known exception (Macario et al. 1999; Zmijewski et al. 2004). We found several studies on Antarctic archaea that showed the response of DnaK in expression levels when cells were exposed to thermal stress. A study of the Antarctic haloarchaea, Halohasta litchfieldiae and Halorubrum lacusprofundi, showed that both possess one set of DnaK-DnaJ-GrpE chaperones. A proteome study showed higher levels at high temperature for DnaK in response to heat stress (Williams et al. 2017). Moreover, Methanosarcina mazei S-6 Hsp70 (DnaK) responded to heat shock by an increase in the production of their transcripts (Clarens et al. 1995; Conway De Macario et al. 1995). In Natrinema sp. J7, the Hsp70 (DnaK) gene allowed an $E$. coli Dnak-null mutant to propagate $\lambda$ phages and grow at $42{ }^{\circ} \mathrm{C}$ (Zhang et al. 2007). Despite the importance of DnaK in eubacteria and eukarya, the archaeal Hsp70 (DnaK) system is commonly found in all mesophilic and some thermophilic organisms. The absence of Hsp70 (DnaK) in various archaea suggest that archaea are aboriginally lacking Hsp70 (DnaK), and different archaea taxa that have it must have received it via lateral gene transfer events from phylogenetically diverse bacteria (Gribaldo et al. 1999).

\section{Eukaryotes}

\section{Ciliates}

As in protozoa, two ciliates, which are endemic in Antarctic coastal seawater, E. focardii and E. nobilii, were found to respond to thermal stress by activating the transcription of their $H s p 70$ genes. La Terza et al. (2001) evaluated Antarctic Euplotes' capacity to activate the expression of genes coding for HSP70. The results were a strong transcriptional activity of $H s p 70$ genes induced in E. nobilii when cells were transferred from $4{ }^{\circ} \mathrm{C}$ to $20^{\circ} \mathrm{C}$, while a much smaller increase was revealed in heat-shocked cells of $E$. focardii. This study reported evidence that two Antarctic species of Euplotes, E. focardii and E. nobilii, sharply diverge from one another in their capacity to activate $H s p 70$ gene transcription in response to thermal stress. In addition, the study on E. focardii by La Terza et al (2004) showed that E. focardii 
did not show any significant $H s p 70$ activation by thermal stress. The cessation of preserving $H s p 70$ gene functions was also seen in the Antarctic fish, T. bernacchii (Hofmann et al. 2000). Though some Antarctic organisms show loss of HSP70 mechanisms in thermal activation response, HSP70 still retains its function for responding to other environmental hazards such as salinity, osmotic shocks, UV radiation, and other environmental stressors.

Podlipaeva et al. (2008) assayed the expression of $\mathrm{Hsp} 70$ in ciliates, comparing Tetrahymena pyriformis with freshwater Paramecium jenningsi and euryhaline P. nephridiatum. In this study, the synthesis of $H s p 70$ was induced in $P$. jenningsi and $P$. nephridiatum after salinity stress. In $T$. pyriformis, salinity stress led to constitutive expression of Hsp70. The differences in the HSP70 chaperone system reaction of these ciliates species may be related to their different salinity resistances. It is known that loss of HSP70 thermal activation is likely to be a common occurrence among Antarctic ectotherms and ciliates that inhabit an environment under constantly cold conditions. Therefore, Antarctic marine organisms, such as ciliates and fish, may evolve convergent losses of their ability to induce an HSP70 protective response to thermal stress. This is possible due to the long periods of isolation in an extremely cold and stable thermal environment (Pucciarelli et al. 2009). It is plausible that such constitutive $H s p 70$ expression in certain species appears enough to prevent irreversible protein aggregation as a result of a variety of environmental stresses. Alternatively, the upregulation of $H s p 70$ in response to heat and salinity stress is acquired to generate thermoprotection and osmotic resistance in the cells. Induced HSP70s importantly act as molecular chaperones preventing cellular damage in cells under conditions of environmental stress. However, it is crucial to understand that the meaning of stress will depend ultimately on the organism and its environmental history. Hence, this shows the important role of HSP70 in adaptation by organisms that inhabit the stably cold Antarctic waters and also habitats with a constantly changing environment.

\section{Algae}

In algae, HSP70 is often used in the prediction of stress tolerance and monitoring environmental changes. In Ulva prolifera, the transcription of $H s p 70$ was upregulated by UV irradiation, heat treatment and salinities induction (Zhang et al. 2012). In the Antarctic ice algae, Chlamydomonas sp. ICE-L, its $H s p 70$ mRNA expression was stimulated when cells were exposed to both cold and heat shock treatments. Moreover, treating the cells with salinity shock using $62 \%$ or $93 \%$ sodium chloride $(\mathrm{NaCl})$ for $2 \mathrm{~h}$, the $H s p 70$ mRNA expression level increased by 3.0- and 2.1-fold, respectively (Liu et al. 2010). Moreover, the study of Plocamium cartilagineum (L. Dix.) showed maximal induction of $\mathrm{Hsp} 70$
mRNA when the alga was incubated at $10{ }^{\circ} \mathrm{C}$ for $1 \mathrm{~h}$, while incubations at higher temperatures or for longer periods reduced the amount of $H s p 70$ mRNA detected (Vayda and Yuan 1994). A study on Symbiodinium sp. demonstrated that the expression of the algal $H s p 70$ gene increased when cells were exposed to heat stress and reduced when exposed to extreme heat stress (Rosic et al. 2011). It was also reported that significant differential $H s p 70$ expression was a result of salinity stress. Symbiotic relationships between Symbiodinium sp. and Exaiptasia pallida showed effects of salinity stress in $H s p 70$ expression in hypo- and hypersaline conditions. The study showed that E. pallida Hsp70 expression increased up to 6-11-fold at high salinities, whereas Symbiodinium Hsp70 expression showed little change at 1.4-2.6fold (Ellison et al. 2017). These data strongly support the importance of $H s p 70$ genes as biomarkers for abiotic stress. In the green alga Chaetomorpha valida, it was reported that real-time polymerase chain reaction (qPCR) detection revealed that the $H s p 70$ gene expression was dramatically upregulated by temperature, desiccation, and salinities induction. This suggests that $H s p 70$ in $C$. valida acts as a stress-responsive gene involved in protecting $C$. valida from abiotic stresses and unfavorable natural environments (Deng et al. 2015). These findings urge for deeper analysis of the use of HSP70s as indicators in abiotic stress.

\section{Plants}

A previous study showed that HSP70s in plants have high similarity to prokaryote HSP70s (DnaK), and the organellelocalized HSP70s, such as mitochondria and chloroplast, are also highly similar to eukaryotic cytosolic HSP70s (Sung et al. 2001). This supports the conserved nature of HSP70 and is consistent with the evolutionary origin for compartmentations of organelles in the eukaryotic organism ( $\mathrm{Yu}$ et al. 2015).

Liu et al. (2014) demonstrated that real-time PCR analysis of the Antarctic moss, P. nutans Hsp $70 \mathrm{cDNA}$, showed that the expression levels of $H s p 70$ increased to 3.34-fold at $24 \mathrm{~h}$ after $4{ }^{\circ} \mathrm{C}$ treatment and increased to 2.74 -fold at $24 \mathrm{~h}$ after $10{ }^{\circ} \mathrm{C}$ treatment. This shows that the upregulation was induced by cold and heat stress. In addition to temperature, previous research has shown that Antarctic $P$. nutans demonstrated adaptation to drought, high salt levels, and UV radiation in the Antarctic that normally limit plant growth (Yao et al. 2019). Drought stress was tested on $H s p 70$ expression levels via water deprivation or with a $20 \%$ (w/v) Polyethylene glycol 6000 (PEG6000) solution. It was found that the expression level of $H s p 70$ increased 9.78-fold after water deprivation for 6 days and 5.35-fold after PEG6000 treatment for $6 \mathrm{~h}$. Previous research implies that the upregulation of $H s p 70$ caused by drought treatment is induced by osmotic stress. This reflects the salinity stress 
of $P$. nutans, where the expression of $H s p 70$ increased to a maximum value of 10.29-fold at $24 \mathrm{~h}$ and increased 8.50fold at $36 \mathrm{~h}$ after $200 \mathrm{mM} \mathrm{NaCl}$ treatment.

Another example of HSP70 expression among Antarctic plants is a quantification study on the accumulation of HSP70 protein in leaf tissue of Deschampsia antarctica Desv. (Poaceae), a grass of the Maritime Antarctic. A study by Reyes et al. (2003) demonstrated that cold-acclimated plants subjected to thermal stress of $35^{\circ} \mathrm{C}$ accumulated HSP70 protein more than control plants subjected to $35^{\circ} \mathrm{C}$. Short-term and long-term heat shock treatment also demonstrated that the cold-acclimated plants responded sooner to heat shock conditions. This shows that this low temperature adapted plant responds well to climate warming and the effects of greenhouse, which are projected to cause an increase in temperatures by several degrees and reduce sea ice and glaciers by one third (Turner et al. 2014). The populations of $D$. antarctica showed reproductive success in warmer conditions in number and size along the Antarctic Peninsula, Byers Peninsula, Livingston Island, Isla Robert and even in Argentine islands (Cortés-Antiquera et al. 2021). Despite the negative effects of global warming on plants, $D$. antarctica obtained the maximum carbon dioxide assimilation rate, improving its photosynthetic performance and growth (Sáez et al. 2017, 2018). It has been reported that the Colobanthus quitensis and D. antarctica which are also endemic of South and Central America have increased in the number and size of populations suggesting an improvement in their reproductive performances and adaptation to warmer climate conditions (Bertini et al. 2021). This implies that $D$. antarctica and $C$. quitensis HSP70s might be used as potential biomarkers to monitor Antarctic environmental conditions. This is also supported by the $H s p 70$ gene expression of the Antarctic ice algae, Chlamydomonas sp. ICE-L, where both cold and heat shock treatments could stimulate $H s p 70$ mRNA expression (Liu et al. 2010). Thus, the $H s p 70$ expression pattern in Antarctic plants offers a great potential indicator for monitoring the environmental condition.

\section{Animals}

In marine animals, changes in temperature or/and salinity can hamper the neuroendocrine responses and chemosensory cues (Ross and Behringer 2019; Vargas-Chacoff et al. 2019). Moreover, global warming, which is causing changes in the temperature and salinity of the Antarctic Ocean, can affect the growth, nutrient intake rate, and oxygen consumption of marine animals, leading to death at more extreme temperatures (Navarro et al. 2019). HSP70s are well known to respond to high temperature and other environmental stresses in a wide range of organisms (Murphy 2013; Yu et al. 2015). In eukaryotes, multiple members of the HSP70 family are known and located in the cytosol as well as in specific subcellular compartments, such as the endoplasmic reticulum lumen and organelles (Schroda et al. 1999). Studies on the $H s p 70$ gene family in animals revealed that the stress-induced $H s p 70 s$ are mainly cytosolic members ( $\mathrm{Yu}$ et al. 2015).

Typically, the genes encoding HSP70s are not expressed or lowly expressed under normal conditions and are quickly upregulated in response to stressors such as heat and salinity. In some reports, $H s p 70$ s are constitutively expressed at all conditions. These can be seen in both the Antarctic fish, T. bernacchii, and the Antarctic ciliate, E. focardii. In response to thermal stress, these two Antarctic marine species responded by constitutively expressing $\mathrm{Hsp} 70$ and showing no or modest upregulation. In the case of the Antarctic Nototheniidae fish, Harpagifer antarcticus, qPCR results for liver, white muscle, and digestive gland tissue demonstrated the downregulation of the $H s p 70$ gene family comprising constitutive $H s c 70$, inducible $H s p 70$ genes and GRP78 (glucose-regulated protein $78 \mathrm{kDa}$ ) during heat shock experiments (Clark et al. 2008a, b, c). Other studies in several other Antarctic fish species showed that $H$. antarcticus displayed both the constitutive expression of $\mathrm{Hsp} 70$ and the absence of a reproducible classical heat shock response via upregulation of the $H s p 70$ genes in response to increased environmental temperatures (Hofmann et al. 2000; Place and Hofmann 2005). The lack of upregulation of $H s p 70$ has been demonstrated in the Antarctic Nototheniidae and other Antarctic sea creatures such as Antarctic sea urchin, $S$. neumayeri (González-Aravena et al. 2018). Similar results were observed in Antarctic sea star, O. validus, and Antarctic gammarid, $P$. gibber, where there was no significant upregulation of $H s p 70$ genes when cells were exposed to acute heat shock experiments at 10 and $15^{\circ} \mathrm{C}$. Instead, $O$. validus $\mathrm{Hsp} 70$ showed an initial decrease of 6.9-fold in relative expression levels after a $2{ }^{\circ} \mathrm{C}$ heat shock time course experiment (Clark et al. 2008b). It was previously reviewed that Antarctic fish may have a depressed or slower stress response compared to temperate animals (Clark and Peck 2009). A previous report showed that the expression mode of $\mathrm{Hsp} 70$ in Antarctic fish has been altered from inducible to constitutive (Place et al. 2004; Place and Hofmann 2005). In these Antarctic fish, HSP70 proteins are produced continuously and have extra housekeeping costs compared to other temperate species, where their production is tightly regulated and induced under stress (Clark et al. 2008a, b, c). Thus, the loss of the classical heat shock response in the Antarctic fish might be related to amino acid requirements and energy priorities for other essential cellular metabolic activities. This is essential to avoid the negative effects of HSP70 overproduction such as impacts on growth, development rate, and fertility (Krebs and Feder 1997). These studies provide an increasing body of evidence to support the idea that constitutive expression of heat shock proteins 
and lack of regulation may be a compensatory mechanism for coping with elevated protein damage at temperatures far from the optimal temperature. This response is believed to be an adaptation to the cold but constant low temperature of the polar sea.

The impact of ocean acidification driven by the increase in $\mathrm{CO}_{2}$ concentration in seawater has been demonstrated to affect many marine animals in internal bicarbonate homeostasis, acid-base regulation as well as energy metabolism. Marine organisms respond to ocean acidification in different ways in which some coral species are known to survive and recover from bleaching caused by ocean warming and salinity change (Kvitt et al. 2011) and reduced pH conditions (Kvitt et al. 2015). In mollusks and corals, the response to ocean acidification has been related to the dissolution of carbonate structures and reduced calcification rate (Sin et al. 2020). The gene expression profiles in the Antarctic coral, Malacobelemnon daytoni, revealed upregulation of $H s p 70$ in response to the short-term low $\mathrm{pH}$ condition (Servetto et al. 2021). Moreover, a substantial upregulation of $H s p 70$ gene transcript levels in L. elliptica mantle tissue was demonstrated in response to $\mathrm{pH}$ levels that were both lowered and elevated relative to existing Antarctic conditions (Cummings et al. 2011). In addition, a long-term, eight-month experiment, which was conducted to compare the physiological responses of Desmophyllum dianthus, resulted in the upregulation of $H s p 70$ gene expression when samples were exposed to two $\mathrm{pCO}_{2} / \mathrm{pH}$ treatments: ambient $\mathrm{pCO} 2$ $(460 \mu \mathrm{atm}, \mathrm{pHT}=8.01)$ and elevated $\mathrm{pCO}_{2}(997 \mu \mathrm{atm}$, $\mathrm{pHT}=7.70)$ (Carreiro-Silva et al. 2014). The upregulation of $H s p 70$ in response to stress exposure either high or low $\mathrm{pH}$ was not unexpected, as either $\mathrm{pH}$ directionality is likely to relate as a stress to marine organisms, stimulating induction of Hsp70. In Acropora millepora, Hsp 70 was not differentially expressed between treatments but was maintained at a high expression levels, probably for the integrity of newly made proteins (Kaniewska et al. 2012). The constitutive overexpression of $H s p 70$ was also reported in the black-chinned tilapia, Sarotherodon melanotheron, when samples were acclimatized to extreme hyper-salinity (Tine et al. 2010). While in the sea star, Anasterias minuta, the interaction of temperature and salinity triggers an increase in $H s p 70$ expression (Arribas et al. 2022). In the Antarctic copepod, T. kingsejongensis, the transcript profile under instantaneous salinity change showed that the mRNA expressions of $H s p 70$ were highly upregulated (Kim et al. 2022). Taken together, most HSP70 family genes generally display increased expression or expressed constitutively after being induced by environmental stress, which shows their functional association with thermal, salinity and $\mathrm{pH}$ stressors but again that can be species dependent.

However, there are reports which demonstrate that some Antarctic species may respond somewhat differently. An intriguing study on $T$. bernacchii showed endoplasmic reticulum (ER)-specialized $H s p 70$ did show moderate increases in the multi-stressor treatment. Although $T$. bernacchii lacked an inducible heat shock response with almost no response for the heat shock protein 90 (HSP90), HSP70, and small HSP families, moderate increases in $H s p 70$ transcripts were found when cells were exposed to temperature and $\mathrm{pCO}_{2}$ stressors simultaneously (Huth and Place 2016). This shows that although previous studies using acute thermal stress suggest no acclimation of $H s p 70$ expression in stress response, the expression of $H s p 70$ s were inducible when $T$. bernacchii was exposed to the multi-stressor condition brought on by increased sea surface temperature and ocean acidification. Another study on $H$. antarcticus showed that the transcription of $H s p 70$ presented significant induction when cells were exposed to a combination of stressors (i.e., an increase in temperature and decrease in salinity), mainly in fish livers (Martínez et al. 2021). These findings are consistent with the response of $H s p 70$ s reported in Eleginops maclovinus, where an increase in the temperature from 12 to $18{ }^{\circ} \mathrm{C}$ induced the overexpression of $H s p 70$ in the liver (Martínez et al. 2020).

In addition, some Antarctic fish can acclimate successfully to higher temperatures such as exposure at $4{ }^{\circ} \mathrm{C}$ (Carpenter and Hofmann 2000; Lowe and Davison 2005; Jin and DeVries 2006; Podrabsky and Somero 2006). The induced thermal tolerance found in T. bernacchii and other Antarctic notothenioids possibly occurs through different mechanisms than those common to other species (Podrabsky and Somero 2006). A recent study by Toullec et al. (2020) demonstrated the upregulation of $H s p 70$ genes in the Antarctic krill, Euphausia superba, after several hours of recovery. Their heat shock treatment was expanded to include a recovery period at $0{ }^{\circ} \mathrm{C}$ for 2,3 and $6 \mathrm{~h}$. Mean normalized expression levels of five $H s p 70$ genes of $E$. superba obtained by qPCR showed no significant expression variation in the initial short heat shock treatment at 3 and $6{ }^{\circ} \mathrm{C}$ for 3 and $6 \mathrm{~h}$ but increased at a much higher level of expression at the $0{ }^{\circ} \mathrm{C}$ recovery period. The lack of initial heat shock response may be due to the need for more time for recovery or that the species has reached its limits and is unable to compensate for variations in the environment. Long-term heat shock experiments during continuous heat shock at $3{ }^{\circ} \mathrm{C}$ for 6 weeks showed that the expression level of $H s p 70$ peaked at different times, thus indicating $H s p 70$ activity beyond $6 \mathrm{~h}$ in response to chronic temperature challenge. In particular, the inducible isoform of $H s p 70$ showed a significant increase in expression after $12 \mathrm{~h}$. This delayed gene expression compared to other organisms might be related to the presence of large constitutive amounts of HSP proteins in Antarctic animals (Place and Hofmann 2005). Nonetheless, this implies the capability of E. superba to upregulate their $H s p 70$ genes in response to 
a thermal shock and broadens the prospects of HSP70s as relevant biomarkers to monitor climate change.

A contrast from that which was found in many coldstenothermal Antarctic organisms with a lack of $H s p 70$ response, Pseudodiamesa branickii (Diptera Chironomidae) was able to activate $H s p 70$ gene transcription in response to thermal stress. Larvae of $P$. branickii showed significant upregulation of the inducible $H s p 70$ gene with increasing temperatures and an over-expression of both the constitutive $H s c 70$ and inducible $H s p 70$ by increasing the time of exposure (Bernabò et al. 2011). Moreover, works on sponges from different latitudes showed that $H s p 70$ s were specifically upregulated in response to thermal stress which was broadly similar to that seen in other sponge species (González-Aravena et al. 2019). Alternatively, the Antarctic marine mollusks, L. elliptica and $N$. concinna, demonstrated significant upregulation of $H s p 70$ gene expression after an acute $2 \mathrm{~h}$ heat shock experiment. This study showed massive differences in the $H s p 70$ upregulation capacity between the two mollusk species, where it reached a maximum of 2000fold in $N$. concinna but only 40-fold in L. elliptica. In this study, which compared the $H s p 70$ gene induction level in $N$. concinna and L. elliptica, two inducible forms of $H s p 70$, designated $H S P 70 A$ and $H S P 70 B$, were characterized from these two Antarctic marine species. The degree of increase was different between HSP7OA and HSP7OB in both species. At $10{ }^{\circ} \mathrm{C}$ exposure, there was no significant change in both the HSP70A and HSP70B genes for N. concinna, but it demonstrated massive upregulation at $15{ }^{\circ} \mathrm{C}$ and $20{ }^{\circ} \mathrm{C}$ for $H S P 70 A$. At $15^{\circ} \mathrm{C}, H S P 70 A$ was massively upregulated by almost 2000 -fold, while $H S P 70 B$ was upregulated by 350 -fold. This indicates that the induction temperature for both inducible forms of $\mathrm{Hsp} 70$ was higher for $\mathrm{N}$. concinna at $15^{\circ} \mathrm{C}$, while the upregulation threshold for HSP70B in $L$. elliptica was statistically significant from $10^{\circ} \mathrm{C}$ (Clark et al. 2008a). Cold stress treatment also showed down regulation of all $H s p 70$ genes in both seasonal environmental sampling and experimental cold manipulation of $N$. concinna. A longer cold treatment of $6 \mathrm{~h}$ also demonstrated a uniform decrease in $H s p 70$ gene expression, where HSP70A levels of expression were significantly reduced by -11.9 -fold (Clark and Peck 2009). In addition, Park et al. (2007) suggested in their study that $H s p 70$ genes in L. elliptica were expressed in response to thermal stress and were upregulated to the highest level after $12 \mathrm{~h}$ of thermal treatment $\left(10^{\circ} \mathrm{C}\right)$.

The ability to activate an $H s p 70$ response in aquatic cold-stenothermal organisms have been reported for the mollusks, N. concinna and L. elliptica (Clark et al. 2008a; Clark and Peck 2009) and the ciliate, Euplotes nobilii (La Terza et al. 2001). In the larvae of Belgica antarctica, $H s p 70$ s were constitutively upregulated during larval life while adults displayed a typical heat shock response that was thermally activated (Rinehart et al. 2006). This constitutive upregulation of the Hsp70s in larvae reflected an adaptation common to Antarctic species which was also found in ciliates (Podlipaeva et al. 2008), notothenioid fishes (Carpenter and Hofmann 2000; Place and Hofmann 2005) and sea urchins (González-Aravena et al. 2018). The difference in $H s p 70$ expression patterns between larvae and adults was possibly related to differences in the thermal stability occupied by these two stages (Rinehart et al. 2006). This reflects the importance of HSP70 as chaperones facilitating the proper protein folding at low temperatures and thermally stable polar marine environment. An increase in the expression level of constitutively expressed $\mathrm{Hsc} 70$, together with an inducible $H s p 70$ family member, after exposure to high temperatures has been observed in other organisms such as the diamondback moth, Plutella xylostella (Sonoda et al. 2006); the shrimp, Penaeus monodon (Chuang et al. 2007); the hymenopteran, Pteromalus puparum (Wang et al. 2008); and the killifish, Fundulus heteroclitus (Fangue et al. 2006). This presents complexity to the application of the $H s p 70$ expression pattern in these Antarctic organisms for a potential biomarker to monitor environmental change in the Antarctic marine ecosystem.

\section{Potential of HSP70 as a biomarker in climate change}

Temperature is known as one of the most prominent abiotic factors, and since the beginning of the century, its pervasive impact on organisms has been of significant ecological concern. In recent times, thermal biology has received great attention in light of climate change and its impact on biodiversity. Over the past few decades, on average, the Southern Ocean has warmed and freshened due to the global greenhouse effect (Swart et al. 2018). If global air temperatures increase by at least $1-3{ }^{\circ} \mathrm{C}$ over the next century, as scientists expect, the coastal Antarctic ecosystems will likely be exposed to further warming and glacier retreat (Bronselaer et al. 2018). The increase in temperature and salinity changes in the West Antarctic Peninsula has affected the Antarctic phytoplankton assemblages (Hernando et al. 2020). Glacier melting due to the fact of climate change causes a decrease in salinity microbial food web dynamics, which affects phytoplankton, bacteria, and other components of the food web in Antarctica (Hernando et al. 2015, 2018).

Hence, identifying the environmental stress response of organisms is becoming particularly significant in our changing environment as we seek to understand how the rise in ocean temperature, change in salinity and acidification due to the fact of global warming define the species ranges. Analysis at the molecular level will allow scientists to explore how Antarctic organisms will be affected in the context of climate change scenarios. All species acquire similar 
and unique adaptation strategies to live within a controlled biological system with significant ecological, physiological and biochemical specializations. The species-specific ability to cope with environmental change is correlated with these adaptations. For instance, if an organism is taken beyond its usual environmental range by changing temperature, salinity, or oxygen availability, the organism becomes vulnerable, a circumstance generally described as stress. This environmental challenge, in turn, activates biochemical responses to mitigate inevitable cellular damage caused by environmental insult and aid recovery. Analysis of the effect of heat and salinity stressors on living systems at a molecular level will aid in understanding the evolutionary adaptation and assist forecasting not only how climate change affects the physiology of organisms but also the degree of the effects of spatial heterogeneity on the diversity of an ecosystem.

In general, HSP70s are considered excellent biomarkers for studying the effects of environmental stressors, emphasizing heat, salinity and acidification stress. The vast studies on HSP70s in Antarctic organisms, ranging from bacteria to eukarya, allow scientists to utilize HSP70s across the taxonomic groups as indicators in ecotoxicology studies. In particular, increases in HSP70s have already been reported in transcriptomics, proteomics, and gene expression studies, documenting different types of heat and salinity stress patterns as has been reported in haloarchaea, $H$. litchfieldiae and H. lacusprofundi (Williams et al. 2017); ciliates, E. focardii and E. nobilii (La Terza et al. 2001); algae, $U$. prolifera (Zhang et al. 2012); moss, P. nutans (Liu et al. 2014); fish, T. bernacchii (Huth and Place 2016); and $H$. antarcticus (Martínez et al. 2021). Therefore, these Antarctic organisms could be used as stress markers to evaluate the expression of a stress protein such as HSP70. Several studies have been conducted on HSP70 to evaluate environmental stressors including increased temperature, salinity, low $\mathrm{pH}$ and, recently, the combined effect of increased temperature and salinity (Martínez et al. 2021; Servetto et al. 2021; Yusof et al. 2021). Recent studies showed that $H s p 70$ could be expressed when cells were exposed to multiple stress conditions (Huth and Place 2016; Martínez et al. 2021; Arribas et al. 2022). This work also demonstrated that the expression of HSP70s showed potential for use in evaluating environmental stress that is often combined with multiple abiotic factors such as heat, salinity and acidification stress.

The potential to determine the susceptibility of a species to stress is best achieved at a molecular level, as sublethal effects can be quantified across a range of functions. Hence, there is now interest in finding molecular biomarkers for environmental stress, with research to date focusing on heat shock response and heat shock proteins/genes (Hsps), especially the HSP70 family of heat shock proteins. The use of highly conserved genes promotes the development of a universal biomarker system. $H s p 70$ genes are highly conserved among organisms, making them relatively easy to clone using degenerate PCR techniques. They were therefore suggested as good candidates for such biomarkers (Tomanek and Sanford 2003; Hamer et al. 2004). Many studies on HSPs have dealt with thermal stress and, especially, the response to heat shock has been widely investigated in numerous animal species. HSP70 has the highest specific activity among stress proteins and, therefore, can be more readily detected. This particular activity generally consists of variants of $H s p 70$ genes that are induced by exposure to stressors, such as thermal, salinity and acidification, and those who are not. Therefore, any change in the specific activity of $H s p 70$ genes during exposure to the stressors would be linked to inducible variants. The overall specific behavior of HSP70 within a biological system can, nonetheless, be used as a non-specific stress measure. In certain conditions, $H s p 70$ induction indicates a specific response which can be used as a biomarker such as the presence and absence of genes, up- or downregulation of genes and proteins, and also relatively high and constant expression in tissues and cells.

Changes in freshwater levels coupled with rapid warming and acidification in seawater are significant physiological stressors that are expected to threaten Antarctic marine animal well-being, particularly when salinity is likely to be an additional stressor to temperature for cold-adapted stenothermal Antarctic species (Navarro et al. 2020). It is noted that the upregulation of $H s p 70$ genes upon exposure to thermal stress or the classical response of heat stress was lacking in several Antarctic organisms such as reported in the Antarctic fish, T. bernacchii. The constitutive gene expression form is presumed to play a vital role in the regulation of protein metabolism and homeostasis in physiological conditions (Parsell and Lindquist 1994). The importance of the constitutive form might reflect a synergic role with the inducible one in the stabilization of the proteins damaged by the heat shock during folding. Proteins that are constantly produced in cells play important defensive role against environmental stressors (Clark et al. 2018). The high levels of constitutive expression of the inducible forms of HSP70 provide more resilient populations in addition to a series of genes involved in a wide range of functions such as apoptosis and immune responses (Barshis et al. 2013). However, the constant production of HSP70 as defence genes is energetically costly hence, genes involved in transcription and translation are elevated as shown in the $N$. concinna expression profiles (Clark et al. 2018). With extensive studies on HSP70 in prokaryotes in eukaryotes in response to thermal challenges and other stressors related to climate change, such as salinity change and acidification, there is a strong justification for the use of HSP70 as a biomarker of environmental relevance. The understanding of how to simulate real climate change scenarios with a period of gradual warming to the 
target temperature will allow scientists to understand more about HSP70's mechanisms in adaptation and tolerance towards stress. As research in cell stress progresses, overall, many Antarctic marine organisms appear able to acclimate, adapt, and perform normal biological functions at temperatures above $4{ }^{\circ} \mathrm{C}$. Such extensive experimental results on cell stress in both short- and long-term experiments allow scientists to develop a robust assay with definitive trends in data. An example is the usage of droplet digital PCR (ddPCR) as an emerging tool for monitoring cell tolerance towards climate change. It was proven that conventional relative quantification of qPCR analysis could be ineffective depending on samples. In contrast, ddPCR analyses resulted in a clear detection of gene expression which possibly explains the discrepancy among conventional methods including PCR and hybridization (Mauvisseau et al. 2019). Moreover, with an excess of sequence data in public databases, it is now possible to clone, identify, and develop assays for HSP70 heat shock response in a series of model and non-model species ranging from bacteria to eukaryotes. Thus, it is recommended that different variants of HSP70 be used as biomarkers to measure the effects of climate change scenarios.

\section{Conclusion}

Extensive literature and research findings on HSP70s have shown strong evidence regarding the importance of HSP70s. DnaK in bacteria and HSP70s in eukaryotes are the major ATP-dependent molecular chaperones that play a key role in the proteostasis network and are involved in stress response. It is undeniable that HSP70 are a vital protein family in both prokaryotes and eukaryotes due to its dominant role in maintaining a steady cellular environment under thermal and salinity stress in living organisms. There has been some discussion and debate as to whether HSP70s are effective environmental biomarkers, particularly in Antarctic organisms with the absence of HSP70 in several Antarctic organisms. Considering the numerous studies on HSP70's various responses compiled in this review, we concluded that the monitoring of HSP70 gene expression and consequent activation and synthesis of HSP70 proteins has great potential to warn about the Antarctic environmental disturbance caused by global warming. Overexpression of HSP70 enables living organisms to reduce the adverse effects caused by climate change in which organisms must survive under prolonged periods of high ambient temperatures. In addition, the constitutive expression of HSP70 may be species-specific associated with longer-term chronic stress and under different bio-geographical distributions (Clark and Peck 2009). These show the flexibility of HSP70 as an environmental biomarker under a number of different conditions over both acute and chronic timescales. Hence, we concluded that
HSP70s have great potential to be used as biomarkers, as scientists can use a wide selection of non-model organisms to investigate the adaptation strategies, tolerance, and changes in the polar environment, especially temperature, salinity and acidification in the Antarctic Ocean. The analysis of HSP70 synthesis will be able to warn about the environmental disturbance caused by climate change in Antarctica. The option of HSP70s as potential biomarkers for thermal and salinity stress effects in Antarctic marine animals is clear. With the technology in physical features and models using satellite and sophisticated programs of the climate system, the integration of biological models is equally important to approach the level of spatial scale for application to biological systems. The usage of HSP70s as biomarkers will provide an advantage in understanding biotic and ecosystem responses towards climate change. Moreover, with the advent of omics technologies, such as droplet digital PCR, sequencer, and microarrays, these will provide access to data on new genomes on a massive scale. Transcription profiling of a wide range of organisms under normal and stressful conditions enables the comprehensive elucidation of HSP70 gene pathways involved in the stress response related to climate change. Soon, scientists will discover the greater resistance capability in some taxa than others and extrapolate the organisms' stress in the context of the global ecosystem. Therefore, the HSP70 family is a great prospect for use as potential biomarkers for environmental protection and the role they may play in the cellular defenses against climate change effects. Overall, the extensive studies on HSP70 results are useful tools to predict a possible future geographic distribution of a wide range of marine species within the context of global warming, particularly thermal stress, salinity change and acidification.

Supplementary Information The online version contains supplementary material available at https://doi.org/10.1007/s00300-022-03006-7.

Acknowledgements We would like to thank the Universiti Malaysia Sabah for the strong support in research and innovation. We would also like to thank the Research and Innovation team at the Biotechnology Research Institute for their administrative and technical support in research and grant management. The authors gratefully thank to the chief editor, Professor Dieter Piepenburg and referees for the constructive comments and recommendations which definitely help to improve the readability and quality of the paper.

Author contributions NAY, AMAM and NMM provided the concept, design, and overall supervision of this study. MM, JC, TYQ, and FNN contributed to the writing. CMWVL contributed to the proofreading and editing of this manuscript. AMAM and NMM also participated in the project discussion. All authors approved and agreed to be accountable for all aspects of the work. All authors have read and agreed to the published version of the manuscript.

Funding This research was funded by Yayasan Penyelidikan Antartika Sultan Mizan (YPASM) (Grant Number GLS0032-2019) and 
the Ministry of Higher Education Malaysia (FRGS/1/2017/STG05/ UMS/02/2). The APC was funded by Universiti Malaysia Sabah.

\section{Declarations}

Conflict of interest The authors declare that they have no competing interests.

Open Access This article is licensed under a Creative Commons Attribution 4.0 International License, which permits use, sharing, adaptation, distribution and reproduction in any medium or format, as long as you give appropriate credit to the original author(s) and the source, provide a link to the Creative Commons licence, and indicate if changes were made. The images or other third party material in this article are included in the article's Creative Commons licence, unless indicated otherwise in a credit line to the material. If material is not included in the article's Creative Commons licence and your intended use is not permitted by statutory regulation or exceeds the permitted use, you will need to obtain permission directly from the copyright holder. To view a copy of this licence, visit http://creativecommons.org/licenses/by/4.0/.

\section{References}

Abdullah-Al-Mahin SS, Higashi C, Matsumoto S, Sonomoto K (2010) Improvement of multiple-stress tolerance and lactic acid production in Lactococcus lactis NZ9000 under conditions of thermal stress by heterologous expression of Escherichia coli DnaK. Appl Environ Microbiol 76:4277-4285. https://doi.org/10.1128/ AEM.02878-09

Angelidis CE, Nova C, Lazaridis I, Kontoyiannis D, Kollias G, Pagoulatos GN (1996) Overexpression of HSP70 in transgenic mice results in increased cell thermotolerance. Transgenics 2:111-117

Anlauf H, D'Croz L, O'Dea A (2011) A corrosive concoction: The combined effects of ocean warming and acidification on the early growth of a stony coral are multiplicative. J Exp Mar Biol Ecol 397:13-20. https://doi.org/10.1016/j.jembe.2010.11.009

Ansoar-Rodríguez Y, Christofoletti CA, Correia JE, Souza RB, Moreira-de-Sousa C, Marcato ACC, Bueno OC, Malaspina O, Silva-Zacarin ECM, Fontanetti CS (2016) Liver alterations in Oreochromis niloticus (pisces) induced by insecticide imidacloprid: histopathology and heat shock protein in situ localization. J Environ Sci Health B 51:881-887. https://doi.org/10.1080/03601 234.2016.1240559

Arribas LP, Alfaya JEF, Palomo MG, Giulianelli S, Vilela RAN, Bigatti G (2022) Ocean warming lead to heat shock protein expression and decrease in the feeding rate of the Patagonian sea star Anasterias minuta. J Exp Mar Biol Ecol 546:151661. https://doi.org/ 10.1016/j.jembe.2021.151661

Barshis DJ, Ladner JT, Oliver TA, Seneca FO, Traylor-Knowles N, Palumbi SR (2013) Genomic basis for coral resilience to climate change. Proc Natl Acad Sci USA 110:1387-1392. https://doi.org/ 10.1073/pnas. 1210224110

Bernabò P, Rebecchi L, Jousson O, Martínez-Guitarte JL, Lencioni $\mathrm{V}$ (2011) Thermotolerance and $h s p 70$ heat shock response in the cold-stenothermal chironomid Pseudodiamesa branickii (NE Italy). Cell Stress Chaperones 16:403-410. https://doi.org/10. 1007/s12192-010-025-5

Bers AV, Momo F, Schloss IR, Abele D (2013) Analysis of trends and sudden changes in long-term environmental data from King George Island (Antarctica): relationships between global climatic oscillations and local system response. Clim Change 116:789803. https://doi.org/10.1007/s10584-012-0523-4

Bertini L, Proietti S, Focaracci F, Canini F, Bravo LA, Rabert C, Caruso C (2021) Identification and validation of new reference genes for accurate quantitative reverse transcriptase-PCR normalization in the Antarctic plant Colobanthus quitensis under abiotic stress conditions. Polar Biol 44:389-405. https://doi.org/ 10.1007/s00300-021-02801-y

Boorstein WR, Ziegelhoffer T, Craig EA (1994) Molecular evolution of the HSP70 multigene family. J Mol Evol 38:1-17. https://doi. org/10.1007/BF00175490

Bronselaer B, Winton M, Griffies SM, Hurlin WJ, Rodgers KB, Sergienko OV, Stouffer RJ, Russell JL (2018) Change in future climate due to Antarctic meltwater. Nature 564:53-58. https://doi. org/10.1038/s41586-018-0712-Z

Byrne M, Ho MA, Koleits L, Price C, King CK, Virtue P, Tilbrook B, Lamare M (2013) Vulnerability of the calcifying larval stage of the Antarctic sea urchin Sterechinus neumayeri to near future ocean acidification and warming. Glob Change Biol 19:2264-2275. https://doi.org/10.1111/gcb.12190

Cárdenas CA, González-Aravena M, Santibañez PA (2018) The importance of local settings: within-year variability in seawater temperature at South Bay Western Antarctic Peninsula. PeerJ 6:e4289. https://doi.org/10.7717/peerj.4289

Carpenter CM, Hofmann GE (2000) Expression of $70 \mathrm{kDa}$ heat shock proteins in Antarctic and New Zealand Notothenioid Fish. Comp Biochem Physiol A 125:229-238. https://doi.org/ 10.1016/S1095-6433(99)00172-5

Carreiro-Silva M, Cerqueira T, Godinho A, Caetano M, Santos RS, Bettencourt R (2014) Molecular mechanisms underlying the physiological responses of the cold-water coral Desmophyllum dianthus to ocean acidification. Coral Reefs 33:465-476. https://doi.org/10.1007/s00338-014-1129-2

Ciechanover A, Kwon YT (2017) Protein quality control by molecular chaperones in neurodegeneration. Front Neurosci 11:185. https://doi.org/10.3389/fnins.2017.00185

Chuang KH, Ho SH, Song YL (2007) Cloning and expression analysis of heat shock cognate 70 gene promoter in tiger shrimp (Penaeus monodon). Gene 405:10-18. https://doi.org/10. 1016/j.gene.2007.08.016

Clarens M, Macario AJL, de Macario EC (1995) The Archaeal dnaKdnaJ gene cluster: organization and expression in the methanogen Methanosarcina mazei. J Mol Bio 250:191-201. https:// doi.org/10.1006/jmbi.1995.0370

Clark MS, Fraser KPP, Burns G, Peck LS (2008a) The HSP70 heat shock response in the Antarctic fish Harpagifer antarcticus. Polar Biol 31:171-180. https://doi.org/10.1007/ s00300-007-0344-5

Clark MS, Fraser KPP, Peck LS (2008b) Antarctic marine molluscs do have an HSP70 heat shock response. Cell Stress Chaperones 13:39-49. https://doi.org/10.1007/s12192-008-0014-8

Clark MS, Fraser KPP, Peck LS (2008c) Lack of an HSP70 heat shock response in two Antarctic marine invertebrates. Polar Biol 31:1059-1065. https://doi.org/10.1007/s00300-008-0447-7

Clark MS, Peck LS (2009) HSP70 heat shock proteins and environmental stress in Antarctic marine organisms: a mini-review. Mar Genom 2:11-18. https://doi.org/10.1016/j.margen.2009.03.003

Clark MS, Thorne MAS, King M, Hipperson H, Hoffman JI, Peck LS (2018) Life in the intertidal: cellular responses, methylation and epigenetics. Funct Ecol 32:1982-1994. https://doi.org/10.1111/ 1365-2435.13077

Coelho MPM, Moreira-de-Sousa C, Souza RB, Ansoar Rodríguez Y, Silva-Zacarin ECM, Fontanetti CS (2017) Toxicity evaluation of vinasse and biossolid sample in diplopod midgut: heat shock protein in situ localization. Environ Sci Pollut Res Int 24:2200722017. https://doi.org/10.1007/s11356-017-9754-2 
Conway De Macario E, Clarens M, Macario AJ (1995) Archaeal grpE: transcription in two different morphologic stages of Methanosarcina mazei and comparison with dnaK and dnaJ. J Bacteriol Res 177:544-550. https://doi.org/10.1128/jb.177.3.544-550.1995

Cortés-Antiquera R, Pizarro M, Contreras RA, Köhler H, Zúñiga GE (2021) Heat shock tolerance in Deschampsia antarctica Desv. cultivated in vitro is mediated by enzymatic and non-enzymatic antioxidants. Front Plant Sci 12:635491. https://doi.org/10.3389/ fpls.2021.635491

Cummings V, Hewitt J, Van Rooyen A, Currie K, Beard S, Thrush S, Norkko J, Barr N, Heath P, Halliday NJ, Sedcole R, Gomez A, McGraw C, Metcalf V (2011) Ocean acidification at high latitudes: potential effects on functioning of the Antarctic bivalve Laternula elliptica. PLoS ONE 6:e16069. https://doi.org/10. 1371/journal.pone.0016069

Deane EE, Woo NYS (2011) Advances and perspectives on the regulation and expression of piscine heat shock proteins. Rev Fish Biol Fish 21:153-185. https://doi.org/10.1007/s11160-010-9164-8

Deng Y, Zhan Z, Tang X, Ding L, Duan D (2015) Molecular cloning and characterization of an Hsp70 gene from the bloom green alga Chaetomorpha valida (Cladophorales, Chlorophyta). J Appl Phycol 27:489-497. https://doi.org/10.1007/ s10811-014-0313-7

Diamant S, Ben-Zvi AP, Bukau B, Goloubinoff P (2000) Sizedependent disaggregation of stable protein aggregates by the DnaK chaperone machinery. J Biol Chem 275:21107-21113. https://doi.org/10.1074/jbc.M001293200

Drozdova P, Bedulina D, Madyarova E, Rivarola-Duarte L, Schreiber S, Stadler PF, Luckenbach T, Timofeyev M (2019) Description of strongly heat-inducible heat shock protein 70 transcripts from Baikal endemic amphipods. Sci Rep 9:8907. https://doi. org/10.1038/s41598-019-45193-0

Ellison MA, Ferrier MD, Carney SL (2017) Salinity stress results in differential Hsp70 expression in the Exaiptasia pallida and Symbiodinium symbiosis. Mar Environ Res 132:63-67. https:// doi.org/10.1016/j.marenvres.2017.10.006

Ericson JA, Ho MA, Miskelly A, King CK, Virtue P, Tilbrook B, Byrne M (2012) Combined effects of two ocean change stressors, warming and acidification, on fertilization and early development of the Antarctic echinoid Sterechinus neumayeri. Polar Biol 35:1027-1034. https://doi.org/10.1007/ s00300-011-1150-7

Evans CG, Chang L, Gestwicki JE (2010) Heat shock protein 70 (Hsp70) as an emerging drug target. J Med Chem 53:4585-4602. https://doi.org/10.1021/jm100054f

Fangue NA, Hofmeister M, Schulte PM (2006) Intraspecific variation in thermal tolerance and heat shock protein gene expression in common killifish, Fundulus heteroclitus. J Exp Biol 209:28592872. https://doi.org/10.1242/jeb.02260

Feder ME, Hofmann GE (1999) Heat-shock proteins, molecular chaperones, and the stress response: evolutionary and ecological physiology. Annu Rev Physiol 61:243-282. https://doi.org/10. 1146/annurev.physiol.61.1.243

Fernández-Fernández MR, Valpuesta JM (2018) Hsp70 chaperone: a master player in protein homeostasis. F1000Research 7:1497. https://doi.org/10.12688/f1000research.15528.1

Fink AL (1999) Chaperone-mediated protein folding. Physiol Rev 79:425-449. https://doi.org/10.1152/physrev.1999.79.2.425

Flaherty KM, Luca-Flaherty C, McKay DB (1990) Three-dimensional structure of the ATPase fragment of a 70K heat-shock cognate protein. Nature 346:623-628. https://doi.org/10.1038/346623a0

Flynn EE, Bjelde BE, Miller NA, Todgham AE (2015) Ocean acidification exerts negative effects during warming conditions in a developing Antarctic fish. Conserv Physiol. https://doi.org/10. 1093/conphys/cov033
Frydman J (2001) Folding of newly translated proteins in vivo: the role of molecular chaperones. Annu Rev Biochem 70:603-647. https://doi.org/10.1146/annurev.biochem.70.1.603

Fuentes V, Alurralde G, Meyer B, Aguirre GE, Canepa A, Wölfl A-C, Hass HC, Williams GN, Schloss IR (2016) Glacial melting: an overlooked threat to Antarctic krill. Sci Rep 6:27234. https://doi. org/10.1038/srep27234

García-Descalzo L, García-López E, Alcázar A, Baquero F, Cid C (2014) Proteomic analysis of the adaptation to warming in the Antarctic bacteria Shewanella frigidimarina. BBA-Proteins Proteom 1844:2229-2240. https://doi.org/10.1016/j.bbapap. 2014.08.006

Genevaux P, Keppel F, Schwager F, Langendijk-Genevaux PS, Hartl FU, Georgopoulos C (2004) In vivo analysis of the overlapping functions of DnaK and trigger factor. EMBO Rep 5:195-200. https://doi.org/10.1038/sj.embor.7400067

Ghazaei C (2017) Role and mechanism of the Hsp70 molecular chaperone machines in bacterial pathogens. J Med Microbiol 66:259265. https://doi.org/10.1099/jmm.0.000429

Gokhale RS, Khosla C (2000) Role of linkers in communication between protein modules. Curr Opin Chem Biol 4:22-27. https://doi.org/10.1016/S1367-5931(99)00046-0

Golledge NR, Keller ED, Gomez N, Naughten KA, Bernales J, Trusel LD, Edwards TL (2019) Global environment consequences of twenty-first-century ice-sheet melt. Nature 566:65-72. https://doi.org/10.1038/s41586-019-0889-9

González-Aravena M, Calfio C, Mercado L, Morales-Lange B, Bethke J, De Lorgeril J, Cárdenas CA (2018) HSP70 from the Antarctic sea urchin Sterechinus neumayeri: molecular characterization and expression in response to heat stress. Biol Res 51:8. https://doi.org/10.1186/s40659-018-0156-9

González-Aravena M, Kenny NJ, Osorio M, Font A, Riesgo A, Cárdenas CA (2019) Warm temperatures, cool sponges: the effect of increased temperatures on the Antarctic sponge Isodictya sp. PeerJ 7:e8088. https://doi.org/10.7717/peerj.8088

Gribaldo S, Lumia V, Creti R, Conway de Macario E, Sanangelantoni A, Cammarano P (1999) Discontinuous occurrence of the hsp70 (DnaK) gene among Archaea and sequence features of HSP70 suggest a novel outlook on phylogenies inferred from this protein. J Bacteriol 181:434-443. https://doi.org/10.1128/ JB.181.2.434-443.1999

Hamer B, Hamer DP, Müller WEG, Batel R (2004) Stress-70 proteins in marine mussel Mytilus galloprovincialis as biomarkers of environmental pollution: a field study. Environ Int 30:873882. https://doi.org/10.1016/j.envint.2004.02.008

Han W, Christen P (2003) Interdomain communication in the molecular chaperone DnaK. Biochem J 369:627-634. https://doi.org/ 10.1042/bj20020943

Hartl FU (1996) Molecular chaperones in cellular protein folding. Nature 381:571-580. https://doi.org/10.1038/381571a0

Hartl FU, Hayer-Hartl M (2002) Molecular chaperones in the cytosol: from nascent chain to folded protein. Science 295:18521858. https://doi.org/10.1126/science. 1068408

Hernando M, Schloss IR, Almandoz GO, Malanga G, Varela DE, De Troch M (2018) Combined effects of temperature and salinity on fatty acid content and lipid damage in Antarctic phytoplankton. J Exp Mar Biol Ecol 503:120-128. https://doi.org/ 10.1016/j.jembe.2018.03.004

Hernando M, Schloss IR, Malanga G, Almandoz GO, Ferreyra GA, Aguiar MB, Puntarulo S (2015) Effects of salinity changes on coastal Antarctic phytoplankton physiology and assemblage composition. J Exp Mar Biol Ecol 466:110-119. https://doi. org/10.1016/j.jembe.2015.02.012

Hernando M, Varela DE, Malanga G, Almandoz GO, Schloss IR (2020) Effects of climate-induced changes in temperature and salinity on phytoplankton physiology and stress responses in 
coastal Antarctica. J Exp Mar Biol Ecol 530-531:151400. https://doi.org/10.1016/j.jembe.2020.151400

Hofmann GE, Buckley BA, Airaksinen S, Keen JE, Somero GN (2000) Heat-shock protein expression is absent in the antarctic fish Trematomus bernacchii (family Nototheniidae). J Exp Biol 203:2331-2339

Hu X, Liu R, Li Y, Wang W, Tai F, Xue R, Li C (2010) Heat shock protein 70 regulates the abscisic acid-induced antioxidant response of maize to combined drought and heat stress. Plant Growth Regul 60:225-235. https://doi.org/10.1007/ s10725-009-9436-2

Huth TJ, Place SP (2016) Transcriptome wide analyses reveal a sustained cellular stress response in the gill tissue of Trematomus bernacchii after acclimation to multiple stressors. BMC Genom 17:127. https://doi.org/10.1186/s12864-016-2454-3

Imamoglu R, Balchin D, Hayer-Hartl M, Hartl FU (2020) Bacterial Hsp70 resolves misfolded states and accelerates productive folding of a multi-domain protein. Nat Commun 11:365. https://doi. org/10.1038/s41467-019-14245-4

IPCC (2018) "Summary for policymakers", in global warming of $15^{\circ} \mathrm{C}$. Waterfield World Meteorological Organization, Geneva

Jäättelä M, Wissing D, Bauer PA, Li GC (1992) Major heat shock protein hsp70 protects tumor cells from tumor necrosis factor cytotoxicity. EMBO J 11:3507-3512

Jayaraman GC, Burne RA (1995) DnaK expression in response to heat shock of Streptococcus mutans. FEMS Microbiol Lett 131:255261. https://doi.org/10.1111/j.1574-6968.1995.tb07785.x

Jin Y, deVries AL (2006) Antifreeze glycoprotein levels in Antarctic notothenioid fishes inhabiting different thermal environments and the effect of warm acclimation. Comp Biochem Physiol B 144:290-300. https://doi.org/10.1016/j.cbpb.2006.03.006

Jinwal UK, Miyata Y, Koren J, Jones JR, Trotter JH, Chang L, O'Leary J, Morgan D, Lee DC, Shults CL, Rousaki A, Weeber EJ, Zuiderweg ERP, Gestwicki JE, Dickey CA (2009) Chemical manipulation of Hsp70 ATPase activity regulates tau stability. J Neurosci 29:12079-12088. https://doi.org/10.1523/JNEUROSCI.3345-09. 2009

Kampinga HH, Craig EA (2010) The HSP70 chaperone machinery: $\mathrm{J}$ proteins as drivers of functional specificity. Nat Rev Mol Cell Biol 11:579-592. https://doi.org/10.1038/nrm2941

Kaniewska P, Campbell PR, Kline DI, Rodriguez-Lanetty M, Miller DJ, Dove S, Hoegh-Guldberg O (2012) Major cellular and physiological impacts of ocean acidification on a reef building coral. PLOS ONE 7:e34659. https://doi.org/10.1371/journal.pone. 0034659

Kawaguchi S, Ishida A, King R, Raymond B, Waller N, Constable A, Nicol S, Wakita M, Ishimatsu A (2013) Risk maps for Antarctic krill under projected Southern Ocean acidification. Nature Clim Change 3:843-847. https://doi.org/10.1038/nclimate1937

Kim BM, Lee Y, Hwang JY, Kim YK, Kim TW, Kim N, Kang S, Kim JH, Rhee JS (2022) Physiological and molecular responses of the Antarctic harpacticoid copepod Tigriopus kingsejongensis to salinity fluctuations - a multigenerational study. Environ Res 204:112075. https://doi.org/10.1016/j.envres.2021.112075

Klaips CL, Jayaraj GC, Hartl FU (2018) Pathways of cellular proteostasis in aging and disease. J Cell Biol 217:51-63. https://doi. org/10.1083/jcb.201709072

Koch M, Bowes G, Ross C, Zhang XH (2012) Climate change and ocean acidification effects on seagrasses and marine macroalgae. Glob Chang Biol 19:103-132. https://doi.org/10.1111/j. 1365-2486.2012.02791.x

Köhler HR, Triebskorn R, Stöcker W, Kloetzel PM, Alberti G (1992) The $70 \mathrm{kD}$ heat shock protein (hsp70) in soil in vertebrates: a possible tool for monitoring environmental toxicants. Arch Environ Contam Toxicol 22:334-338. https://doi.org/10.1007/BF002 12095
Krebs RA, Feder ME (1997) Natural variation in the expression of the heat-shock protein hsp70 in a population of Drosophila melanogaster and its correlation with tolerance of ecologically relevant thermal stress. Evolution 51:173-179. https://doi.org/10. 1111/j.1558-5646.1997.tb02398.x

Kvitt H, Rosenfeld H, Zandbank K, Tchernov D (2011) Regulation of apoptotic pathways by Stylophora pistillata (Anthozoa, Pocilloporidae) to survive thermal stress and bleaching. PLoS ONE 6:e28665. https://doi.org/10.1371/journal.pone.0028665

Kvitt H, Kramarsky-Winter E, Maor-Landaw K, Zandbank K, Kushmaro A, Rosenfeld H, Fine M, Tchernov D (2015) Breakdown of coral colonial form under reduced $\mathrm{pH}$ conditions is initiated in polyps and mediated through apoptosis. Proc Natl Acad Sci USA 112:2082-2086. https://doi.org/10.1073/pnas.1419621112

La Terza A, Papa G, Miceli C, Luporini P (2001) Divergence between two Antarctic species of the ciliate Euplotes, E. focardii and E. nobilii, in the expression of heat-shock protein 70 genes. Mol Ecol 10:1061-1067. https://doi.org/10.1046/j.1365-294X.2001. 01242.x

La Terza A, Miceli C, Luporini P (2004) The gene for the heat-shock protein 70 of Euplotes focardii, an Antarctic psychrophilic ciliate. Antarct Sci 16:23-28. https://doi.org/10.1017/S095410200 4001774

La Terza A, Passini V, Barchetta S, Luporini P (2007) Adaptive evolution of the heat-shock response in the Antarctic psychrophilic ciliate, Euplotes focardii: hints from a comparative determination of the hsp70 gene structure. Antarct Sci 19:239-244. https://doi.org/10.1017/S0954102007000314

Lang BJ, Guerrero ME, Prince TL, Okusha Y, Bonorino C, Calderwood SK (2021) The functions and regulation of heat shock proteins; key orchestrators of proteostasis and the heat shock response. Arch Toxicol 95:1943-1970. https://doi.org/10.1007/ s00204-021-03070-8

Li GC, Li L, Liu RY, Rehman M, Lee WM (1992) Heat shock protein hsp70 protects cells from thermal stress even after deletion of its ATP-binding domain. Proc Natl Acad Sci USA 89:20362040. https://doi.org/10.1073/pnas.89.6.2036

Liu S, Zhang P, Cong B, Liu C, Lin X, Shen J, Huang X (2010) Molecular cloning and expression analysis of a cytosolic Hsp70 gene from Antarctic ice algae Chlamydomonas sp. ICE-L. Extremophiles 14:329-337. https://doi.org/10.1007/ s00792-010-0313-8

Liu S, Wang J, Cong B, Huang X, Chen K, Zhang P (2014) Characterization and expression analysis of a mitochondrial heat-shock protein 70 gene from the Antarctic moss Pohlia nutans. Polar Biol 37:1145-1155. https://doi.org/10.1007/s00300-014-1508-8

Lowe CJ, Davison W (2005) Plasma osmolarity, glucose concentration and erythrocyte responses of two Antarctic notothenioid fishes to acute and chronic thermal change. J Fish Biol 67:752-766. https://doi.org/10.1111/j.0022-1112.2005.00775.X

Lu J, Zhang X, Wu Y, Sheng Y, Li W, Wang W (2021) Energy landscape remodeling mechanism of Hsp70-chaperone-accelerated protein folding. Biophys J 120:1971-1983. https://doi.org/10. 1016/j.bpj.2021.03.013

Macario AJL, Lange M, Ahring BK, De Macario EC (1999) Stress genes and proteins in the Archaea. Microbiol Mol Biol Rev 63:923-967. https://doi.org/10.1128/MMBR.63.4.923-967.1999

Makumire S, Revaprasadu N, Shonhai A (2015) DnaK protein alleviates toxicity induced by citrate-coated gold nanoparticles in Escherichia coli. PLoS ONE 10:e121243. https://doi.org/10. 1371/journal.pone.0121243

Martínez D, Vargas-Lagos C, Saravia J, Oyarzún R, Loncoman C, Pontigo JP, Vargas-Chacoff L (2020) Cellular stress responses of Eleginops maclovinus fish injected with Piscirickettsia salmonis and submitted to thermal stress. Cell Stress Chaperones 25:93-104. https://doi.org/10.1007/s12192-019-01051-6 
Martínez D, Moncada-Kopp C, Paschke K, Navarro JM, VargasChacoff L (2021) Warming and freshening activate the transcription of genes involved in the cellular stress response in Harpagifer antarcticus. Fish Physiol Biochem 47:533-546. https://doi. org/10.1007/s10695-021-00931-y

Mayer MP, Bukau B (2005) Hsp70 chaperones: cellular functions and molecular mechanism. Cell Mol Life Sci 62:670-684. https://doi. org/10.1007/s00018-004-4464-6

Mayer MP (2021) The Hsp70-chaperone machines in bacteria. Front Mol Biosci 8:694012. https://doi.org/10.3389/fmolb.2021. 694012

Mauvisseau Q, Davy-Bowker J, Bulling M, Brys R, Neyrinck S, Troth C, Sweet M (2019) Combining ddPCR and environmental DNA to improve detection capabilities of a critically endangered freshwater invertebrate. Sci Rep 9:14064. https://doi.org/10.1038/ s41598-019-50571-9

Mello DF, Oliveira ES, Vieira RC, Simões E, Trevisan R, Dafre AL, Barraco MA (2012) Cellular and transcriptional responses of Crassostrea gigas hemocytes exposed in vitro to brevetoxin (PbTx-2). Mar Drugs 10:583-597. https://doi.org/10.3390/ md10030583

Mekkes L, Sepúlveda-Rodríguez G, Bielkinaitė G, Wall-Palmer D, Brummer GJA, Dämmer LK, Huisman J, van Loon E, Renema W, Peijnenburg KTCA (2021) Effects of ocean acidification on calcification of the sub-Antarctic pteropod Limacina retroversa. Front Mar Sci 8:581432. https://doi.org/10.3389/fmars.2021. 581432

Metzger DC, Hemmerhansen J, Schulte PM (2016) Conserved structure and expression of hsp70 paralogs in teleost fishes. Comp Biochem Phys D 18:10-20. https://doi.org/10.1016/j.cbd.2016. 01.007

Mimura N (2013) Sea-level rise caused by climate change and its implications for society. Proc Jpn Acad B Phys Biol Sci 89:281-301. https://doi.org/10.2183/pjab.89.281

Mishra SR, Palai TK (2014) Importance of heat shock protein 70 in livestock-at cellular level. J Mol Pathophysiol 3:30-32. https:// doi.org/10.5455/jmp.20141028023220

Morris J, Thatje S, Hauton C (2013) The use of stress-70 proteins in physiology: a re-appraisal. Mol Ecol 22:494-1502. https://doi. org/10.1111/mec.12216

Moyes CD, Schulte PM (2010) Princípios de fisiologia animal. Artmed Editore, Brazil

Murphy ME (2013) The HSP70 family and cancer. Carcinogenesis 34:1181-1188. https://doi.org/10.1093/carcin/bgt111

Nadeau D, Plante I, Morrow G, Tanguay RM (2001) Evaluation for Hsp70 as a biomarker of effect of pollutants on the earth worm Lumbricus terrestres. Cell Stress Chaperones 6:153-163. https:// doi.org/10.1379/1466-1268(2001)006\%3c0153:efhaab\%3e2.0. $\operatorname{co} ; 2$

Navarro JM, Paschke K, Ortiz A, Vargas-Chacoff L, Pardo LM, Valdivia N (2019) The Antarctic fish Harpagifer antarcticus under current temperatures and salinities and future scenarios of climate change. Prog Oceanogr 174:37-43. https://doi.org/10. 1016/j.pocean.2018.09.001

Navarro JM, Détrée C, Morley SA, Cárdenas L, Ortiz A, VargasChacoff L, Paschke K, Gallardo P, Laure Guillemin M, Ortiz A, Gonzalez-Wevar C (2020) Evaluating the effects of ocean warming and freshening on the physiological energetics and transcriptomic response of the Antarctic limpet Nacella concinna. Sci Total Environ 748:142448. https://doi.org/10.1016/j.scito tenv.2020.142448

Park H, Ahn IY, Lee HE (2007) Expression of heat shock protein 70 in the thermally stressed Antarctic clam Laternula elliptica. Cell Stress Chaperones 12:275. https://doi.org/10.1379/csc-271.1

Parsell DA, Lindquist S (1993) The function of heat-shock proteins in stress tolerance degradation and reactivation of damaged proteins. Annu Rev Genet 27:437-496. https://doi.org/10.1146/ annurev.ge.27.120193.002253

Parsell DA, Lindquist S (1994) Heat shock proteins and stress tolerance. In: Morimoto RI, Tissiéres A, Georgopoulos C (eds) The biology of heat shock proteins and molecular chaperones. Cold Spring Harbor Laboratory Press, Cold Spring Harbor, pp 457-494

Peck LS (2005) Prospects for surviving climate change in Antarctic aquatic species. Front Zool 2:1-8. https://doi.org/10.1186/ 1742-9994-2-9

Peck LS, Morley SA, Clark MS (2010) Poor acclimation capacities in Antarctic marine ectotherms. Mar Biol 157:2051-2059. https:// doi.org/10.1007/s00227-010-1473-x

Peisker K, Chiabudini M, Rospert S (2010) The ribosome-bound Hsp70 homolog Ssb of Saccharomyces cerevisiae. Biochim Biophys Acta Mol Cell Res 1803:662-672. https://doi.org/10. 1016/j.bbamcr.2010.03.005

Pelham H, Lewis M, Lindquist S (1984) Expression of a Drosophila heat shock protein in mammalian cells: transient association with nucleoli after heat shock. Philos Trans R Soc Lond B Biol Sci 307:301-307. https://doi.org/10.1098/rstb.1984.0131

Place SP, Hofmann GE (2005) Constitutive expression of a stress inducible heat shock protein gene, $h s p 70$, in a phylogenetically distant Antarctic fish. Polar Biol 28:261-267. https://doi.org/10. 1007/s00300-004-0697-y

Place SP, Zippay ML, Hofmann GE (2004) Constitutive roles for inducible genes: evidence for the alteration in expression of the inducible hsp70 gene in Antarctic notothenioid fishes. Am J Physiol Regul Integr Comp Physiol 287:429-436. https://doi. org/10.1152/ajpregu.00223.2004

Podlipaeva YI, Smurov AO, Goodkov AV (2008) Expression of heatshock protein $70 \mathrm{kDa}$ in Tetrahymena pyriformis during cell adaptation to salinity changes in the medium. Cell Tissue Biol 2:373-375. https://doi.org/10.1134/S1990519X08040056

Podrabsky JE, Somero GN (2006) Inducible heat tolerance in Antarctic nothothenioid fishes. Polar Biol 30:39-43. https://doi.org/10. 1007/s00300-006-0157-y

Pucciarelli S, La Terza A, Ballarini P, Barchetta S, Yu T, Marziale F, Passini V, Methé B, Detrich HW 3rd, Miceli C (2009) Molecular cold-adaptation of protein function and gene regulation: the case for comparative genomic analyses in marine ciliated protozoa. Mar Genom 2:57-66. https://doi.org/10.1016/j.margen.2009.03. 008

Qu B, Jia Y, Liu Y, Wang H, Ren G, Wang H (2015) The detection and role of heat shock protein 70 in various nondisease conditions and disease conditions: a literature review. Cell Stress Chaperones 20:885-892. https://doi.org/10.1007/s12192-015-0618-8

Radons J (2016) The human HSP70 family of chaperones: where do we stand? Cell Stress Chaperones 21:379-404. https://doi.org/ 10.1007/s12192-016-0676-6

Reddy Chichili VP, Kumar V, Sivaraman J (2013) Linkers in the structural biology of protein-protein interactions. Protein Sci 22:153167. https://doi.org/10.1002/pro.2206

Reyes MA, Corcuera LJ, Cardemil L (2003) Accumulation of HSP70 in Deschampsia antarctica Desv. leaves under thermal stress. Antarct Sci 15:345-352. https://doi.org/10.1017/S095410200 3001366

Rignot E, Mouginot J, Scheuchl B, van den Broeke M, van Wessem MJ, Morlighem M (2019) Four decades of Antarctic ice sheet mass balance from 1979-2017. Proc Natl Acad Sci USA 116:10951103. https://doi.org/10.1073/pnas. 1812883116

Rinehart JP, Hayward SA, Elnitsky MA, Sandro LH, Lee RE Jr, Denlinger DL (2006) Continuous up-regulation of heat shock proteins in larvae, but not adults, of a polar insect. Proc Natl Acad Sci USA 103:14223-14227. https://doi.org/10.1073/pnas.06068 40103 
Roncarati D, Scarlato V (2017) Regulation of heat-shock genes in bacteria: from signal sensing to gene expression output. FEMS Microbiol Rev 41:49-574. https://doi.org/10.1093/femsre/fux015

Rosic NN, Pernice M, Dove S, Dunn S, Hoegh-Guldberg O (2011) Gene expression profiles of cytosolic heat shock proteins Hsp70 and Hsp90 from symbiotic dinoflagellates in response to thermal stress: possible implications for coral bleaching. Cell Stress Chaperones 16:69-80. https://doi.org/10.1007/ s12192-010-0222-x

Ross E, Behringer D (2019) Changes in temperature, $\mathrm{pH}$, and salinity affect the sheltering responses of Caribbean spiny lobsters to chemosensory cues. Sci Rep 9:4375. https://doi.org/10.1038/ s41598-019-40832-y

Ruiz DM, Turowski VR, Murakami MT (2016) Effects of the linker region on the structure and function of modular GH5 cellulases. Sci Rep 6:1-13. https://doi.org/10.1038/srep28504

Sabirzhanov B, Stoica BA, Hanscom M, Piao CS, Faden AL (2012) Over-expression of HSP70 attenuates caspase dependent and caspase independent pathways and inhibits neuronalapoptosis. J Neurochem 123:542-554. https://doi.org/10.1111/j.1471-4159. 2012.07927.x

Sáez P, Bravo L, Cavieres L, Vallejos V, Sanhueza C, Font-Carrascosa M, Gil-Pelegrín E, Javier Peguero-Pina J, Galmés J (2017) Photosynthetic limitations in two Antarctic vascular plants: importance of leaf anatomical traits and Rubisco kinetic parameters. J Exp Bot 68:2871-2883. https://doi.org/10.1093/jxb/erx148

Sáez P, Cavieres LA, Galmés J, Gil-Pelegrin E, Peguero-Pina JJ, Sancho-Knapik D, Vivas M, Sanhueza C, Ramírez CF, Rivera BK, Corcuera LJ, Bravo LA (2018) In situ warming in the Antarctic: effects on growth and photosynthesis in Antarctic vascular plants. New Phytol 218:1406-1418. https://doi.org/10.1111/nph. 15124

Schramm FD, Heinrich K, Thuring M, Bernhardt J, Jonas K (2017) An Essential regulatory function of the DnaK chaperone dictates the decision between proliferation and maintenance in Caulobacter crescentus. Plos Genet 13:7148. https://doi.org/10.1371/journal. pgen. 1007148

Schram JB, Schoenrock KM, McClintock JB, Amsler CD, Angus RA (2017) Ocean warming and acidification alter Antarctic macroalgal biochemical composition but not amphipod grazer feeding preferences. Mar Ecol Prog Ser 581:45-56. https://doi.org/10. 3354/meps 12308

Schroda M, Vallon O, Wollman FA, Beck CF (1999) A chloroplasttargeted heat shock protein 70 (HSP70) contributes to the photoprotection and repair of photosystem II during and after photoinhibition. Plant Cell 11:1165-1178. https://doi.org/10.1105/ tpc.11.6.1165

Seibel BA, Maas AE, Dierssen HM (2012) Energetic plasticity underlies a variable response to ocean acidification in the pteropod, Limacina helicina Antarctica. Plos One 7:e30464. https://doi. org/10.1371/journal.pone.0030464

Servetto N, de Aranzamendi MC, Bettencourt R, Held C, Abele D, Movilla J, González G, Bustos DM, Sahade R (2021) Molecular mechanisms underlying responses of the Antarctic coral Malacobelemnon daytoni to ocean acidification. Mar Environ Res 170:105430. https://doi.org/10.1016/j.marenvres.2021.105430

Sharma D, Masison DC (2009) Hsp70 structure, function, regulation and influence on yeast prions. Protein Pept Lett 16:571-581. https://doi.org/10.2174/092986609788490230

Siegert M, Atkinson A, Banwell A, Brandon M, Convey P, Davies B, Downie R, Edwards T, Hubbard B, Marshall G, Rogelj J, Rumble J, Stroeve J, Vaughan D (2019) The Antarctic Peninsula under a $1.5^{\circ} \mathrm{C}$ global warming scenario. Front Environ Sci. https://doi. org/10.3389/fenvs.2019.00102

Silvano A, Rintoul SR, Peña-Molino B, Hobbs WR, van Wijk E, Aoki S, Tamura T, Williams GD (2018) Freshening by glacial meltwater enhances melting of ice shelves and reduces formation of Antarctic bottom water. Sci Adv. https://doi.org/10.1126/ sciadv.aap9467

Silva-Zacarin ECM, Chauzat MP, Zeggane S, Drajnudel P, Schurr F, Faucon JP, Malaspina O, Engler JA (2012) Protocol for optimization of histological, histochemical and immunohistochemical analyses of larval tissues: application in histopathology of honey bee. Curr Microsc Contrib Adv Sci Technol 1:696-703

Silver JT, Noble EG (2012) Regulation of survival gene hsp70. Cell Stress Chaperones 17:1-9. https://doi.org/10.1007/ s12192-011-0290-6

Sin F, Ahn IY, Park S, Kim T (2020) Effects of low pH and low salinity induced by meltwater inflow on the behavior and physical condition of the Antarctic limpet Nacella concinna. J Mar Sci Eng 8:822. https://doi.org/10.3390/jmse8100822

Sinnasamy S, Noordin NM, MacRae TH, Bin Abdullah MI, Bossier P, Wahid ME, Noriaki A, Sung YY (2016) Ingestion of food pellets containing Escherichia coli overexpressing the heatshock protein DnaK protects Penaeus vannamei (Boone) against Vibrio harveyi (Baumann) infection. J Fish Dis 39:577584. https://doi.org/10.1111/jfd.12390

Sonoda S, Ashfaq M, Tsumuki H (2006) Cloning and nucleonde sequencing of three heat shock protein genes (hsp90, hsc70, and hsp19.5) from the diamondback moth, Plutella xylostella (L.) and their expression in relation to developmental stage and temperature. Arch Insect Biochem Physiol 62:80-90. https:// doi.org/10.1002/arch.20124

Sørensen JG (2010) Application of heat shock protein expression for detecting natural adaptation and exposure to stress in natural populations. Curr Zool 56:703-713. https://doi.org/10.1093/ czoolo/56.6.703

Suckling CC, Clark MS, Richard J, Morley SA, Thorne MAS, Harper EM, Peck LS (2015) Adult acclimation to combined temperature and $\mathrm{pH}$ stressors significantly enhances reproductive outcomes compared to short-term exposures. J Anim Ecol 84:773-784. https://doi.org/10.1111/1365-2656.12316

Sugimoto S, Arita-Morioka KI, Terao A, Yamanaka K, Ogura T, Mizunoe Y (2018) Multitasking of Hsp70 chaperone in the biogenesis of bacterial functional amyloids. Commun Biol 1:52. https://doi.org/10.1038/s42003-018-0056-0

Sugimoto S, Nakayama J, Fukuda D, Sonezaki S, Watanabe M, Tosukhowong A, Sonomoto K (2003) Effect of heterologous expression of molecular chaperone DnaK from Tetragenococcus halophilus on salinity adaptation of Escherichia coli. J Biosci Bioeng 96:129-133. https://doi.org/10.1016/S13891723(03)90114-9

Sung DY (2001) Comprehensive expression profile analysis of the Arabidopsis Hsp70 gene family. Plant Physiol 126:789-800. https://doi.org/10.1104/pp.126.2.789

Sung DY, Kaplan F, Guy CL (2001) Plant Hsp70 molecular chaperones: protein structure, gene family, expression and function. Physiol Plant 113:443-451. https://doi.org/10.1034/j.1399-3054. 2001.1130402.x

Swart NC, Gille ST, Fyfe JC, Gillett NP (2018) Recent Southern Ocean warming and freshening driven by greenhouse gas emissions and ozone depletion. Nature Geosci 11:836-841. https://doi.org/10. 1038/s41561-018-0226-1

Taylor DA, Thompson EL, Nair SV, Raftos DA (2013) Differential effects of metal contamination on the transcript expression of immune-and stress-response genes in the Sydney Rock oyster, Saccostrea glomerata. Environ Pollut 17:65-71. https://doi.org/ 10.1016/j.envpol.2013.02.027

Tine M, Bonhomme F, McKenzie DJ, Durand JD (2010) Differential expression of the heat shock protein Hsp70 in natural populations of the tilapia, Sarotherodon melanotheron, acclimatised to 
a range of environmental salinities. BMC Ecol 10:11. https://doi. org/10.1186/1472-6785-10-11

Tomanek L, Sanford E (2003) Heat-shock protein 70 (Hsp70) as a biochemical stress indicator: an experimental field test in two congeneric intertidal gastropods (genus: Tegula). Biol Bull 205:276-284. https://doi.org/10.2307/1543291

Toullec JY, Cascella K, Ruault S, Geffroy A, Lorieux D, Montagné N, Ollivaux C, Lee CY (2020) Antarctic krill (Euphausia superba) in a warming ocean: thermotolerance and deciphering Hsp70 responses. Cell Stress Chaperones 25:519-531. https://doi.org/ 10.1007/s12192-020-01103-2

Turner J, Barrand NE, Bracegirdle TJ, Convey P, Hodgson DA, Jarvis $M$ et al (2014) Antarctic climate change and the environment: an update. Polar Record 50:237-259. https://doi.org/10.1017/S0032 247413000296

Vargas-Chacoff L, Muñoz JL, Ocampo D, Paschke K, Navarro JM (2019) The effect of alterations in salinity and temperature on neuroendocrine responses of the Antarctic fish Harpagifer antarcticus. Comp Biochem Physiol A Mol Integr Physiol 235:131137. https://doi.org/10.1016/j.cbpa.2019.05.029

Vayda ME, Yuan ML (1994) The heat shock response of an antarctic alga is evident at $5^{\circ} \mathrm{C}$. Plant Mol Biol 24:229-233. https://doi. org/10.1007/BF00040590

Wang H, Dong S, Li K, Hu C, Ye G (2008) A heat shock cognate 70 gene in the endoparasitoid, Pteromalus puparum, and its expression in relation to thermal stress. BMB Rep 41:388-393. https:// doi.org/10.5483/BMBRep.2008.41.5.388

Wang J, Russell BD, Ding MW, Dong YW (2018) Ocean acidification increases the sensitivity of and variability in physiological responses of an intertidal limpet to thermal stress. Biogeosciences 15:2803-2817. https://doi.org/10.5194/bg-15-2803-2018

Williams TJ, Liao Y, Ye J, Kuchel RP, Poljak A, Raftery MJ, Cavicchioli R (2017) Cold adaptation of the Antarctic haloarchaea Halohasta litchfieldiae and Halorubrum lacusprofundi. Environ Microbiol 19:2210-2227. https://doi.org/10.1111/1462-2920. 13705

Wruck F, Avellaneda MJ, Koers EJ, Minde DP, Mayer MP, Kramer G, Mashaghi A, Tans SJ (2018) Protein folding mediated by trigger factor and Hsp70: new insights from single-molecule approaches. J Mol Biol 430:438-449. https://doi.org/10.1016/j.jmb.2017.09. 004

Xu X, Jiao L, Feng X, Ran J, Liang X, Zhao R (2017) Heterogeneous expression of DnaK gene from Alicyclobacillus acidoterrestris improves the resistance of Escherichia coli against heat and acid stress. AMB Express 7:36. https://doi.org/10.1186/ s13568-017-0337-x

Xu K, Xu H, Han Z (2018) Genome-wide identification of Hsp70 genes in the large yellow croaker (Larimichthys crocea) and their regulated expression under cold and heat stress. Genes 9:590. https:// doi.org/10.3390/genes9120590
Yao X, Wang T, Wang H, Liu H, Liu S, Zhao Q, Chen K, Zhang P (2019) Identification, characterization and expression analysis of the chalcone synthase family in the Antarctic moss Pohlia nutans. Antarc Sci 31:23-33. https://doi.org/10.1017/S0954 102018000470

Yoshimune K, Galkin A, Kulakova L, Yoshimura T, Esaki N (2005) Cold-active DnaK of an Antarctic psychrotroph Shewanella sp. Ac10 supporting the growth of dnaK-null mutant of Escherichia coli at cold temperatures. Extremophiles 9:145-150. https://doi. org/10.1007/s00792-004-0429-9

Young JC, Barral JM, Hartl FU (2003) More than folding: localized functions of cytosolic chaperones. Trends Biochem Sci 28:541547. https://doi.org/10.1016/j.tibs.2003.08.009

Yu A, Li P, Tang T, Wang J, Chen Y, Liu L (2015) Roles of Hsp70s in stress responses of microorganisms, plants, and animals. BioMed Res Int. https://doi.org/10.1155/2015/510319

Yusof NA, Charles J, Wan Mahadi W, Abdul Murad AM, Mahadi NM (2021) Characterization of inducible HSP70 genes in an Antarctic yeast, Glaciozyma antarctica PI12, in response to thermal stress. Microorganisms 9:2069. https://doi.org/10.3390/micro organisms 9102069

Zanger M, Alberti G, Kuhn M, Kölher HR (1996) The stress-70 protein family in diplopods: induction and characterization. J Comp Physiol B 165:622-627. https://doi.org/10.1007/BF00301130

Zhang H, Lin L, Zeng C, Shen P, Huang YP (2007) Cloning and characterization of a haloarchaeal heat shock protein 70 functionally expressed in Escherichia coli. FEMS Microbiol Lett 275:168174. https://doi.org/10.1111/j.1574-6968.2007.00881.x

Zhang H, Li W, Li J, Fu W, Yao J, Duan D (2012) Characterization and expression analysis of hsp70 gene from Ulva prolifera J. Agardh (Chlorophycophyta, Chlorophyceae). Mar Genomics 5:53-58. https://doi.org/10.1016/j.margen.2011.10.001

Zhu X, Zhao X, Burkholder WF, Gragerov A, Ogata CM, Gottesman ME, Hendrickson WA (1996) Structural analysis of substrate binding by the molecular chaperone DnaK. Science 272:16061614. https://doi.org/10.1126/science.272.5268.1606

Zmijewski MA, Macario AJ, Lipińska B (2004) Functional similarities and differences of an archaeal Hsp70(DnaK) stress protein compared with its homologue from the bacterium Escherichia coli. J Mol Biol 336:539-549. https://doi.org/10.1016/j.jmb. 2003.12.053

Zuiderweg ER, Hightower LE, Gestwicki JE (2017) The remarkable multivalency of the Hsp70 chaperones. Cell Stress Chaperones 22:173-189. https://doi.org/10.1007/s12192-017-0776-y

Publisher's Note Springer Nature remains neutral with regard to jurisdictional claims in published maps and institutional affiliations. 